\title{
Characterising Brazilian biomass burning emissions using WRF-Chem with MOSAIC sectional aerosol
}

\author{
S. Archer-Nicholls ${ }^{1,}{ }^{*}$, D. Lowe ${ }^{1}$, E. Darbyshire ${ }^{1}$, W. T. Morgan ${ }^{1}$, M. M. Bela ${ }^{2}$, G. Pereira ${ }^{3}$, J. Trembath ${ }^{4,1}$, \\ J. W. Kaiser ${ }^{5,6,7}$, K. M. Longo ${ }^{8}$, S. R. Freitas ${ }^{8,9}$, H. Coe ${ }^{1}$, and G. McFiggans ${ }^{1}$ \\ ${ }^{1}$ Centre for Atmospheric Sciences, School of Earth, Atmospheric and Environmental Sciences, University of Manchester, \\ Manchester, UK \\ ${ }^{2}$ Laboratory for Atmospheric and Space Physics, University of Colorado, Boulder, CO, USA \\ ${ }^{3}$ Department of Geoscience (DEGEO), Federal University of São João del Rei (UFSJ), São João del Rei, Brazil \\ ${ }^{4}$ Facility for Airborne Atmospheric Measurements (FAAM), Cranfield University, Bedfordshire, UK \\ ${ }^{5}$ King's College London (KCL), London, UK \\ ${ }^{6}$ European Centre for Medium-range Weather Forecasts, Reading, UK \\ ${ }^{7}$ Max Planck Institute for Chemistry, Mainz, Germany \\ ${ }^{8}$ Centre for Earth System Science (CCST), National Institute for Space Research (INPE), São José dos Campos, Brazil \\ ${ }^{9}$ Centre for Weather Forecast and Climate Studies, National Institute for Space Research (INPE), Cachoeira Paulista, Brazil \\ *now at: National Centre for Atmospheric Research (NCAR), Boulder, CO, USA
}

Correspondence to: G. McFiggans (g.mcfiggans@manchester.ac.uk)

Received: 4 September 2014 - Published in Geosci. Model Dev. Discuss.: 17 September 2014

Revised: 31 January 2015 - Accepted: 6 February 2015 - Published: 12 March 2015

\begin{abstract}
The South American Biomass Burning Analysis (SAMBBA) field campaign took detailed in situ flight measurements of aerosol during the 2012 dry season to characterise biomass burning aerosol and improve understanding of its impacts on weather and climate. Developments have been made to the Weather Research and Forecast model with chemistry (WRF-Chem) model to improve the representation of biomass burning aerosol in the region, by coupling a sectional aerosol scheme to the plume-rise parameterisation. Brazilian Biomass Burning Emissions Model (3BEM) fire emissions are used, prepared using PREP-CHEM-SRC, and mapped to CBM-Z and MOSAIC species. Model results have been evaluated against remote sensing products, AERONET sites, and four case studies of flight measurements from the SAMBBA campaign.

WRF-Chem predicted layers of elevated aerosol loadings $\left(5-20 \mu \mathrm{g} \mathrm{sm}^{-3}\right)$ of particulate organic matter at high altitude $(6-8 \mathrm{~km})$ over tropical forest regions, while flight measurements showed a sharp decrease above $2-4 \mathrm{~km}$ altitude. This difference was attributed to the plume-rise parameterisation overestimating injection height. The 3BEM emissions product was modified using estimates of active fire size and
\end{abstract}

burned area for the 2012 fire season, which reduced the fire size. The enhancement factor for fire emissions was increased from 1.3 to 5 to retain reasonable aerosol optical depths (AODs). The smaller fire size lowered the injection height of the emissions, but WRF-Chem still showed elevated aerosol loadings between $4-5 \mathrm{~km}$ altitude. Over eastern cerrado (savannah-like) regions, both modelled and measured aerosol loadings decreased above approximately $4 \mathrm{~km}$ altitude.

Compared with MODIS satellite data and AERONET sites, WRF-Chem represented AOD magnitude well (between $0.3-1.5$ ) over western tropical forest fire regions in the first half of the campaign, but tended to over-predict them in the second half, when precipitation was more significant. Over eastern cerrado regions, WRF-Chem tended to underpredict AODs. Modelled aerosol loadings in the east were higher in the modified emission scenario. The primary organic matter to black carbon ratio was typically between 8 10 in WRF-Chem. This was lower than the western flight measurements (interquartile range of 11.6-15.7 in B734, 14.7-24.0 in B739), but similar to the eastern flight B742 (8.1-10.4). However, single scattering albedo was close to 
measured over the western flights (0.87-0.89 in model; $0.86-$ 0.91 in flight B734, and 0.81-0.95 in flight B739 measurements) but too high over the eastern flight B742 (0.86-0.87 in model, $0.79-0.82$ in measurements). This suggests that improvements are needed to both modelled aerosol composition and optical properties calculations in WRF-Chem.

\section{Introduction}

Biomass burning in South America is a globally significant source of carbonaceous aerosol (black carbon (BC) and organic carbon (OC)) (Streets et al., 2004). As well as seriously impacting on the health of the local population (Ignotti et al., 2010; de Andrade Filho et al., 2013), this biomass burning aerosol (BBA) influences the climate on a regional and global scale (Andreae et al., 2004; Zhang et al., 2009; Boucher et al., 2013). BBA can impact weather and climate directly, through interaction with radiation (Haywood and Boucher, 2000), and indirectly, by acting as cloud condensation nuclei (CCN), changing cloud optical properties, lifetime and capacity to initiate precipitation (McFiggans et al., 2006). Aerosol optical properties and suitability as $\mathrm{CCN}$ are both highly sensitive to the size distribution and composition of the aerosol population (Bond and Bergstrom, 2006; Abdul-Razzak and Ghan, 2002; McFiggans et al., 2006). Modelling the impacts of BBA on a regional scale requires a fully coupled "online" approach, with detailed descriptions of the aerosol properties and two-way interactions between the aerosol, radiation and cloud processes (Wang et al., 2006; Wang and Christopher, 2006; Grell and Baklanov, 2011).

High-quality emissions are essential for running chemical transport or coupled models. PREP-CHEM-SRC is a preprocessor, designed to combine data from multiple global emission databases to produce anthropogenic, biogenic and biomass burning gridded emission maps (Freitas et al., 2011). Originally developed for the CCATT-BRAMS model (Freitas et al., 2009; Longo et al., 2010), it has been extended for use with the Weather Research and Forecast model with Chemistry (WRF-Chem, Grell et al., 2011). PREP-CHEMSRC can generate fire emissions using either the GFEDv2 inventory to produce 8-day averages (Van der Werf et al., 2006), or daily maps using the Brazilian Biomass Burning Emission Model (3BEM) (Longo et al., 2010). 3BEM has been shown to improve modelled predictions of $\mathrm{CO}$ compared to the lower-resolution GFEDv2 data set (Longo et al., 2010).

Both of these inventories use a traditional "bottom-up" approach, whereby emissions for each species ([i]) are estimated by multiplying emission factors $\left(\mathrm{EF}^{[\mathrm{i}]}\right)$ with an estimate of the burned biomass. Satellite data is used to quantify global fire activity in terms of fire count, observed burnt area or fire radiative power (FRP), and subsequently apply properties such as fuel load and combustion completeness from model calculations or limited field and laboratory mea- surements. The fire properties can be very difficult to measure, resulting in large uncertainties in the emissions (Van der Werf et al., 2010; Ichoku et al., 2012; Kaiser et al., 2012; Zhang et al., 2014). Newer, "top-down" approaches to producing fire emissions systematically include information from large-scale smoke plume observations, e.g. in flux inversion from satellite observations (Huneeus et al., 2012; Ichoku and Ellison, 2013), or enhanced aerosols in Kaiser et al. (2012). These methods show a lot of promise for being able to produce near real-time fire emissions for air quality forecasting, although there are difficulties related to the retrieval algorithms and consistency between different data sources (Pereira et al., 2009). Measurements of FRP are also generally limited to cloud-free regions, and are affected by the time of satellite passover and obstructions of line of sight to the fire, for example by tall trees (Kaiser et al., 2012). This can lead to biases in fire emissions in some regions of the globe (Andela et al., 2013).

The high temperatures of open vegetation fires produce flaming emissions with substantial associated buoyancy. In large fires, the rising air mass can induce convection forming so-called pyrocumulus clouds, which inject emissions high above the planetary boundary layer (Andreae et al., 2001). The height of the plume can vary hugely, depending on season, the biome being burned, atmospheric stability conditions and size of fire (Val Martin et al., 2010; Sofiev et al., 2013). Many global models mix emissions within the boundary layer or specify an injection height. For example, Dentener et al. (2006) provides recommended mixing heights for different biomass burning regions for global models: tropical fires in the lower $1 \mathrm{~km}$, temperate fires in the lower $2 \mathrm{~km}$ and boreal up to $6 \mathrm{~km}$. Wang et al. (2006); Yang et al. (2013) and Wang et al. (2013) specify injection heights of 1.2, 0.8 and $0.7 \mathrm{~km}$ for fires in Central America, Sub-Sahara and Southeast Asia respectively, producing results that compare well with ground-based and remote observations. However, failing to account for the largest fires which penetrate above the boundary layer may result in the underestimation of emissions into the free troposphere (Colarco et al., 2004; Ichoku et al., 2012).

A plume-rise parameterisation that can be embedded into regional transport models was developed by Freitas et al. (2007). The 1-D plume-rise parameterisation was initially implemented in the CCATT-BRAMS model (Freitas et al., 2009; Longo et al., 2010). Freitas et al. (2007) have shown improved representation of the vertical profile of carbon monoxide (CO) compared to measurements from the 2002 SMOCC campaign when using the plume-rise parameterisation. This parameterisation has been successfully adapted into WRF-Chem (Grell et al., 2005), to be used with the RADM (Stockwell et al., 1990) or RACM (Stockwell et al., 1997) chemical mechanisms, and GOCART (Chin et al., 2000) or MADE/SORGAM (Ackermann et al., 1998) aerosol. It has been used in many studies, for example to investigate the impact of Alaskan wildfires on weather fore- 
casts (Grell et al., 2011); to study the effects of BBA on clouds, deep convection and precipitation in the Amazon (Wu et al., 2011a, b); and evaluating the impact of fire emissions on ozone $\left(\mathrm{O}_{3}\right)$ formation (Bela et al., 2015).

While improvements have been observed when using the plume-rise parameterisation in some studies, care should be taken. There are difficulties in using a parameterisation to represent such a complex non-linear process, as the properties needed (such as fire size, buoyancy and entrainment rate) are difficult to constrain, and in some cases impossible to measure, potentially leading to large errors (Ichoku et al., 2012). Indications of the plume-rise over-predicting injection height have been observed. For example, Wu et al. (2011a) found clear-sky aerosol extinction levels between 800 and $100 \mathrm{hPa}$ to be higher in WRF-Chem when comparing against CALIPSO satellite observations, although they were unsure how much of this discrepancy was due to the plume-rise parameterisation and how much from convective transport. Figure 5 in Sofiev et al. (2013) shows most Amazonian plumes to be below $2.5 \mathrm{~km}$, while Fig. 3 in Freitas et al. (2011) models mid-afternoon South American tropical forest injection heights at between 4 and $9 \mathrm{~km}$.

Having aerosol injected into the wrong portion of the vertical column can have many implications. Accurate injection height is required to capture long-range transport of fire emissions (Colarco et al., 2004). The main loss-processes for BBA are wash-out and wet-deposition (Taylor et al., 2014), therefore aerosol above cloud will likely remain in the atmosphere for longer and be transported further from source. In addition, the effect of $\mathrm{BC}$ on atmospheric heating rates is different at different altitudes, becoming more important aloft (Samset and Myhre, 2011; Ban-Weiss et al., 2011; Samset et al., 2013).

This study aims to critically evaluate the plume-rise parameterisation in WRF-Chem against in situ flight measurements over Brazil. The work has been carried out as part of the South American Biomass Burning Analysis (SAMBBA) project, an international collaboration that was formed to better understand and reduce the uncertainties associated with the impacts of biomass burning in South America on regional and global climate, air quality, and ecosystems. The observational phase of SAMBBA consisted of an airborne measurement campaign using the UK Facility for Airborne Atmospheric Measurement (FAAM) BAe-146 research aircraft (Morgan et al., 2013), alongside a longer term ground-based deployment (Brito et al., 2014).

The SAMBBA modelling campaign consists of a hierarchy of models across a range of scales, from the cloudresolving to the global. WRF-Chem is being applied to better understand the properties and impacts of BBA at a regional scale. This study describes the developments being made to the WRF-Chem model to improve the applicability of the model for this task. The MOdel for Simulating Aerosol Interactions with Chemistry (MOSAIC) (Zaveri et al., 2008) aerosol mechanism has been used with the plume-rise pa- rameterisation in order to improve the physical description and size distribution of modelled BBA. Work has also been conducted to modify the input parameters used by the 3BEM emissions and the plume-rise parameterisation in order to better control the injection height of $\mathrm{BB}$ emissions.

Model runs in this study have been carried out using a modified version of WRF-Chem v3.4.1. Model results are critically assessed against remote measurements of aerosol optical depth (AOD), from satellites and groundbased AERONET stations (Holben et al., 2001), and in situ measurements from the BAe-146 aircraft campaign. This is aimed at characterising the horizontal and vertical distribution of the regional haze, evaluating the behaviour of the plume-rise parameterisation, and comparing the composition, size distribution and optical properties of the aerosol population with a high-resolution data source. With the aerosol distribution and properties characterised, the model configuration can be justifiably used to investigate the impacts of the aerosol on regional weather and climate in future studies.

\section{Model, emissions and the plume-rise parameterisation description}

\subsection{WRF-Chem and the sectional MOSAIC aerosol mechanism}

WRF-Chem is a regional, fully-coupled "online" model (Grell et al., 2005), where all prognostic meteorological, chemical and aerosol variables are integrated on the same time step and are transported using the same advection and physical parameterisations. This makes it ideal for investigating the impacts of atmospheric composition on weather at a regional scale (Grell and Baklanov, 2011; Baklanov et al., 2014). For this study, the MOSAIC aerosol (Fast et al., 2006; Zaveri et al., 2008) and CBM-Z gas phase (Zaveri and Peters, 1999) mechanisms are used. MOSAIC uses a sectional representation of aerosol size distribution, with detailed aerosol interactions with radiation and clouds described by Chapman et al. (2009). The Modal Aerosol Dynamics model for Europe (MADE) scheme (Ackermann et al., 1998) has also been used with WRF-Chem for investigating aerosolradiation-cloud interactions (e.g. Grell et al., 2011; Wu et al., 2011b). However, the sectional MOSAIC scheme allows for a more nuanced representation of particle composition variation across eight size bins as opposed to three modes, and does not a priori assume log-normal aerosol size distributions. It is, however, significantly more expensive to run than the modal scheme.

The aerosol size distribution in MOSAIC is described by eight size bins spanning a dry particle diameter $\left(D_{\mathrm{p}}\right)$ range of $39 \mathrm{~nm}$ to $10 \mu \mathrm{m}$ (see Table 1). The chemical constituents of the aerosol are assumed to be internally mixed within each bin, and externally mixed between bins. MOSAIC carries 
Table 1. Fractional apportionment of particulate emissions across the eight MOSAIC size bins, showing range of particle diameters for each bin, primary anthropogenic emission size fraction and biomass burning emission fractions, based on Janhäll et al. (2010).

\begin{tabular}{cccccccc}
\hline Bin 1 & Bin 2 & Bin 3 & Bin 4 & Bin 5 & Bin 6 & Bin 7 & Bin 8 \\
\hline Particle dry diameter $(\mathrm{nm})$ & & & & \\
\hline $39.1-78.1$ & $78.1-156$ & $156-313$ & $313-625$ & $625-1250$ & $1250-2500$ & $2500-5000$ & $5000-10000$ \\
\hline Primary anthropogenic aerosol emission size fractions (fine mode, $<2.5 \mu \mathrm{m})$ & & \\
\hline 0.06 & 0.045 & 0.245 & 0.40 & 0.10 & 0.15 & 0.0 & 0.0 \\
\hline Biomass burning aerosol emission size fractions, based on Janhäll et al. (2010) & & 0.0 \\
\hline 0.0092 & 0.1385 & 0.4548 & 0.3388 & 0.0567 & 0.0020 & 0.0 & 0.0 \\
\hline
\end{tabular}

five inorganic ions, plus three other aerosol species: black carbon (BC); particulate organic mass (POM); and other inorganics (OIN), which include crustal and dust particles (Zaveri et al., 2008). Secondary organic aerosol (SOA) has been incorporated into MOSAIC using the volatility basis set (VBS) (Shrivastava et al., 2011, 2013). However, this was thought to be experimental at the time of study and so not used. Further work is ongoing to incorporate the VBS to study SOA formation and impacts over the SAMBBA period.

The most important chemical component in determining aerosol radiative absorption is $\mathrm{BC}$, due to the high imaginary component of its complex refractive index (1.95-0.79i at $550 \mathrm{~nm}$, as recommended by Bond and Bergstrom, 2006). The absorbing properties of $\mathrm{BC}$ can be enhanced by the nonabsorbing aerosol components with which it is mixed (Bond et al., 2006, 2013). To simulate this, a "mixing-rule" is employed to calculate the bulk complex refractive index of each bin (Ackermann and Toon, 1982). Bond et al. (2006) strongly recommend not using a volume-averaging mixing rule, as it tends to artificially overestimate the absorption enhancement of BC. For this study, a Maxwell-Garnet mixing-rule has been used. This treats the $\mathrm{BC}$ as small particles randomly distributed within a well-mixed matrix composed of the other chemical components.

Mie calculations are used to first find the optical properties of each bin (Toon and Ackerman, 1981), then summed over all bins to give the bulk optical properties of the aerosol population: the extinction $\left(b_{\text {ext }}\right)$; scattering coefficient $\left(b_{\text {scat }}\right)$; absorption coefficient $\left(b_{\mathrm{abs}}\right)$; single scattering albedo $\left(\omega_{0}\right)$; and asymmetry factor for scattering $(g)$. Each of these is defined as a function of $\lambda$, with $\omega_{0}$ being the ratio of scattering to extinction:

$\omega_{0}=\frac{b_{\text {scat }}}{b_{\text {scat }}+b_{\text {abs }}}=\frac{b_{\text {scat }}}{b_{\text {ext }}}$.

Full descriptions of the aerosol optical calculations in WRFChem are described by Fast et al. (2006) and Barnard et al. (2010).

\subsection{Brazilian biomass burning emissions model}

The 3BEM fire emissions product uses daily data of detected fires from several satellite products: the Moderate Resolution Imaging Spectroradiometer (MODIS) (Giglio et al., 2003); the Geostationary Operational Environmental Satellite-Wildfire Automated Biomass Burning Algorithm (GOES WFABBA, cimss.ssec.wisc.edu/goes/burn/wfabba. html; Prins et al., 1998); and the Brazilian National Institute for Space Research (INPE) fire product, which uses the Advanced Very High Resolution Radiometer (AVHRR) onboard the NOAA polar orbiting satellite series (www.cptec.inpe.br/ queimadas; Setzer and Pereira, 1991). A filter algorithm that removes fires within $1 \mathrm{~km}$ of each other is used to prevent double counting between data sets (Longo et al., 2010).

Each fire pixel is cross-referenced against $1 \mathrm{~km}$ resolution maps of vegetation and land use for the year 2000 (Olson et al., 2000; Sestini et al., 2003). The fire is assigned one of four biomes: tropical forest; extra-tropical forest; savannah/cerrado; or grassland. Each biome has an associated carbon density $\left(\alpha_{\mathrm{veg}}\right)$ and combustion factor $\left(\beta_{\mathrm{veg}}\right)$. Emission factors $\left(\mathrm{EF}_{\mathrm{veg}}^{[\mathrm{i}]}\right)$ for each biome type are taken from Andreae and Merlet (2001). These are further scaled by an estimated total burned area $\left(A_{\text {fire }}\right)$, which cannot be directly measured from satellite products in real time, although it may be estimated from fire radiative product (FRP) if suitable data is available. Some fires detected by the WFABBA product have $A_{\text {fire }}$ estimated using the Dozier method (Dozier, 1981, http://wfabba.ssec.wisc.edu/ongoing.html). If this is not available (as is the case for fires detected with the MODIS and INPE products), a burned area of 22.8 ha is used for all vegetation types (Longo et al., 2010). Finally, the fire emissions may need to be scaled up by an enhancement factor $\left(f_{x}\right)$ in order to account for uncertainties and produce physically realistic AODs. These factors are combined to give the emitted mass $\left(M^{[\mathrm{i}]}\right)$ of each species [i]:

$M^{[\mathrm{i}]}=\alpha_{\mathrm{veg}} \cdot \beta_{\mathrm{veg}} \cdot \mathrm{EF}_{\mathrm{veg}}^{[\mathrm{i}]} \cdot A_{\text {fire }} \cdot f_{x}$.

By default, $f_{x}$ is set to 1.3 for South American fires in PREP-CHEM-SRC v1.4. Enhancement factors such as this 
have been applied to many emission products and models, in order to bring bottom-up inventories in line with top-down constraints (Kaiser et al., 2012; Tosca et al., 2013). Values of $f_{x}$ in the literature typically range from 2 to 5 . For example, Wu et al. (2011a) multiplied 3BEM OC and BC surface aerosol emissions by a factor of 5 when simulating the 2006 fire season, Tosca et al. (2013) used an enhancement factor of 2.4 for South American fires using the GFEDv3 inventory with the CAM-5 model, and Kaiser et al. (2012) recommend scaling GFASv1.0 particulate emissions by a factor of 3.4. The need for this factor highlights the difficulties and uncertainties in estimating fire emissions using current observations and understanding. Zhang et al. (2014) have shown existing emission inventories can differ by a factor of 10 in some locations, although top-down estimates tend to show less variation.

\subsection{Plume-rise parameterisation}

The Freitas et al. (2007) plume-rise parameterisation applies a 1-D cloud-parcel model to each grid-column within the WRF-Chem model domain that contains a fire. The full set of equations are described in detail by Freitas et al. (2007, 2010). The parameterisation calculates an initial plume buoyancy, which depends on biome burned (with forest fires releasing more heat than savannah or grassland fires), and ambient environmental conditions along the column retrieved from the parent model. The microphysical parameterisation of Kessler (1969), with accretion and ice formation of Ogura and Takahashi (1971), is used to compute whether convection occurs and the latent energy released if so. Lower and upper estimates of heat flux are used to give lower and upper limits of the injection height. The total fire emissions are split between smouldering and flaming phases, with the flaming fraction emitted between the elevated injection heights, while smouldering emissions are emitted into the lowest mode level.

The main loss of buoyancy results from entrainment of the surrounding air into the plume:

$$
\frac{\partial w}{\partial t}+w \frac{\partial w}{\partial z}=-\left(\lambda_{\text {entr }}+\delta_{\text {entr }}\right) w
$$

where $w$ is the vertical speed of the plume, and $\lambda_{\text {entr }}$ and $\delta_{\text {entr }}$ are the lateral and shear entrainment terms respectively. $\lambda_{\text {entr }}$ is given by:

$\lambda_{\text {entr }}=\frac{2 \alpha}{R}|w|$,

where $R$ is the radius of the plume, $w$ the vertical velocity of the plume and $\alpha$ the dynamic entrainment constant (Freitas et al., 2007), taken to be 0.05 for good agreement with the Active Tracer High-resolution Atmospheric Model (ATHAM) model simulations (Freitas et al., 2010). Freitas et al. (2010) have expanded the parameterisation to include entrainment of shear wind as well as vertical:

$\delta_{\mathrm{entr}}=\frac{2}{\pi R}\left(u_{\mathrm{e}}-u\right)$

where $u$ and $u_{\mathrm{e}}$ are the horizontal wind speeds of the plume and environmental respectively. Note that $\left(u_{\mathrm{e}}-u\right)$ in Eq. (5) is formulated as a scaler difference, implicitly assuming the environmental and plume winds are in the same direction.

The plume radius $R$ is derived from the active size of the fire $\left(S_{\text {fire }}\right)$, assuming the cross-section of the plume to be circular (i.e. $R \propto \sqrt{S_{\text {fire }}}$ ). As both $\lambda_{\text {entr }}$ and $\delta_{\text {entr }}$ are inversely proportional to $R$, larger fires undergo less entrainment and have higher injection heights (Freitas et al., 2010).

\section{Model and emission product developments}

This section of the paper presents development work carried out to improve BBA representation within WRF-Chem with sectional aerosol. The developments are: modification of PREP-CHEM-SRC to update fire size and area; mapping PREP-CHEM-SRC emissions to CBM-Z and MOSAIC; and deriving boundary conditions from the MACC-II product in order to capture long-range transport of BBA.

\subsection{Updating fire size estimates for the 2012 biomass burning season}

The plume-rise parameterisation in WRF-Chem shows a tendency towards overestimating the injection height of flaming emissions, as will be shown in the results section in this paper. Ichoku et al. (2012) suggest restraining the plume height using remote measurements of plume height, such as the MISR satellite. For this work, the inputs of the parameterisation have been refined with the aim of improving the predictive capacity of the injection height calculation.

There are several assumptions built into the 3BEM emissions and plume-rise setup, which may make it prone to having a positive bias. Firstly, there has been a downward trend in fire emissions since the late 1990s and early 2000s (Artaxo et al., 2013). Much of the evaluation of the plume-rise parameterisation and 3BEM emissions product has used data from 2002 (Freitas et al., 2007, 2009; Longo et al., 2010). In using the relatively large average burned area estimate of 22.8 ha, we may be simulating large fires more representative of the previous decade than the modern day. Secondly, the active fire size $\left(S_{\text {fire }}\right)$ used by the plume-rise parameterisation is equal to the total burned area $\left(A_{\text {fire }}\right)$ used to calculate the emitted mass. It is not reasonable to assume that the actively burning portion of a fire is the same as the total burned area. Fires are known to spread along a front (Viegas, 1998), and this behaviour should be approximated in the equations used to calculate the plume-rise.

A number of methods for deriving fire size from satellite products have been developed. Dozier (1981) proposed a bi-spectral approach that utilises the estimated radiance at 
4 and $11 \mu \mathrm{m}$. However, inaccuracies in data acquisition and the digital processing required (for example, co-registration between bands with distinct spatial resolutions and point spread functions, sensor noise and spectral atmospheric interference) could generate large errors in fire size estimation (Giglio and Kendall, 2001; Giglio and Justice, 2003). As a consequence, a number of modifications to the Dozier method have been proposed (Peterson and Wang, 2013; Peterson et al., 2013; Shimabukuro et al., 2013; Giglio and Schroeder, 2014). Peterson et al. (2014) have developed a probabilistic method for estimating the emission injection height based on FRP and retrieved burned area products from MODIS for use over boreal forests. However, fires that occur within the biomes specific to the Amazon and cerrado regions present distinct behaviours (Arai et al., 2011), for which the majority of these schemes have not been calibrated and validated.

For this study, updated estimates of burned area for the 2012 season have been used, acquired from a pre-operational product of CPTEC/INPE (Shimabukuro et al., 2013). In this product, burned area and active fire size are estimated through FRP and fire radiative energy (FRE) based coefficients to different types of vegetation in South America (grassland, herbaceous, scrublands, forest, and agriculture), derived from simultaneous observations of Thematic Mapper (TM) and Enhanced Thematic Mapper Plus (ETM+) images of Landsat 5 and Landsat 7, respectively. MODIS FRP values were used to estimate the fire size using:

$\operatorname{GRID}_{(\text {lon,lat,FRP,LULC) }}=$

$$
\sum_{x=-\alpha}^{\alpha} \sum_{y=-\beta}^{\beta}(\vartheta(x, y) \operatorname{FRP}(\operatorname{lon}+x, \text { lat }+y)
$$

$\vartheta(x, y) \operatorname{LULC}($ lon $+x$, lat $+y)) A_{\mathrm{c}}$,

where $\vartheta(x, y)$ represents the convolution mask of $M \times N$ size (rows $\times$ columns), FRP is the estimated MODIS FRP derived from MOD14 and MYD14 products, LULC is the land cover type derived from MCD12Q1 product, and $A_{\mathrm{c}}$ is the fire size coefficient $\left(0.00021-0.00029 \mathrm{~km}^{2} \mathrm{MW}^{-1}\right)$. GRID is the fire size $\left(S_{\text {fire }}\right)$ defined for all points in which the mask of $M \times$ $N$ size completely overlaps the grid (lon $\in[\alpha, M-\alpha]$, lat $\in$ $[\beta, N-\beta])$. The same approach is applied to derive $A_{\text {fire }}$ by replacing FRP with FRE, as described in Shimabukuro et al. (2013).

Table 2 shows estimates of mean $A_{\text {fire }}$ and $S_{\text {fire }}$ for the 2012 Brazilian fire season, made using the above method. The estimates are dependent on biome (in a similar fashion to $\mathrm{EF}_{\mathrm{veg}}^{[\mathrm{i}]}, \alpha_{\mathrm{veg}}$ and $\beta_{\mathrm{veg}}$ in Eq. 2). As the data was collated for South America over 2012, it should provide more representative estimates of burned area and fire size for the SAMBBA study, given the downward trend in fires over the past decade. $S_{\text {fire }}$ is some 10 to 20 times smaller than 22.8 ha, depending on the biome, meaning the entrainment rate is increased by a factor between 3 and 5. The modified 3bem_emissions.f90 code for PREP-CHEM-SRC v1.4 is included in the Supplement, with instructions on how to modify for another campaign.

Reducing the estimated $A_{\text {fire }}$ to a more reasonable size also reduces the total emitted mass. It was found that this resulted in unrealistically low AODs. Previous models have used higher factors to get reasonable AODs as discussed in Sect. 2.2. For this study $f_{x}$ has been increased from 1.3 to 5. This has been estimated based on the reduction of tropical forest $A_{\text {fire }}$ by approximately a factor of 5 from the original default area of 22.8 ha, while the other biomes are between a third and half the size. As forest fires are the dominant source of emissions in the region, this maintains similar magnitudes of particulate emissions so the study can focus on the implications of the injection height changes.

\subsection{Coupling PREP-CHEM-SRC emissions with CBM-Z MOSAIC}

The emissions generated by PREP-CHEM-SRC are made with the RADM2 and GOCART speciation. For the gasphase emissions, we have adapted the mappings used for anthropogenic RADM2 speciations to CBM-Z within WRF$\mathrm{Chem}$. The excess carbon from longer chained hydrocarbons are added to the CBM-Z species PAR, OLET and OLEI, as described in Zaveri and Peters (1999). Biomass burning flaming emissions are distributed within the model vertical column using the injection heights calculated by the plume-rise parameterisation.

Emissions of BBA are usually observed in two size modes, a sub-micron accumulation mode, which makes up the majority of the particulate number and mass, plus a coarse mode made up of a lower number of larger particles (Reid and Hobbs, 1998). The fine mode is mostly organic compounds, with around $10 \% \mathrm{BC}$ and inorganic species respectively. The coarse mode is made up of dust, ash, carbon aggregates and unburned fuel (Reid et al., 2005; Janhäll et al., 2010). PREP-CHEM-SRC produces emission values for BC, OC, $\mathrm{PM}_{2.5}$ and $\mathrm{PM}_{10}$, based on the factors in Andreae and Merlet (2001). For this study all BC and OC are assumed to be included in the $\mathrm{PM}_{2.5}$ fraction of emissions. Biomass burning OC emissions have been converted to particulate organic matter (POM), multiplying by a factor of 1.5 , following Reid et al. (2005). Similarly anthropogenic OC emissions have been multiplied by a factor of 1.6 (Turpin and Lim, 2001) to yield POM. All emitted particulate mass that is not BC or $\mathrm{POM}$ is assumed to be unreactive inorganic in composition, and mapped to other inorganics (OIN).

Evidence from the measurements of very fresh plumes suggest that in the few seconds after burning, there are a large number of small particles that rapidly coagulate (Reid and Hobbs, 1998). After a few minutes, the distribution generally has a single large accumulation mode, sometimes with a smaller coarse mode (Janhäll et al., 2010). Some measure- 
Table 2. Table of fire area and size, derived from MODIS FRP measurements for the 2012 Brazilian fire season.

\begin{tabular}{lrrrr}
\hline Biome & $\begin{array}{r}\text { Number of } \\
\text { data points }\end{array}$ & $\begin{array}{r}\text { Burned area } \\
A_{\text {fire }}[\text { ha }]\end{array}$ & $\begin{array}{r}\text { Active fire size } \\
S_{\text {fire }}[\text { ha }]\end{array}$ & $\begin{array}{r}\text { Ratio } \\
\left(S_{\text {fire }} / A_{\text {fire }}\right)\end{array}$ \\
\hline Forest & 191386 & $4.3 \pm 8.3$ & $1.15 \pm 2.30$ & 0.267 \\
Mixed forest & 1756 & $10.63 \pm 12.16$ & $2.45 \pm 3.01$ & 0.305 \\
Scrublands & 95681 & $9.13 \pm 12.0$ & $2.15 \pm 2.30$ & 0.235 \\
Savanna/cerrado & 226493 & $7.80 \pm 9.30$ & $1.90 \pm 3.20$ & 0.244 \\
Cropland & 36667 & $9.72 \pm 10.4$ & $1.33 \pm 2.46$ & 0.137 \\
\hline
\end{tabular}

ments suggest changes to $\mathrm{CCN}$, size distribution and $\omega_{0}$ occur over the first $2-4 \mathrm{~h}$ of ageing through SOA formation (Reid et al., 1998; Vakkari et al., 2014). However, these processes cannot be parameterised within this version of the model. A geometric mean diameter $\left(D_{\mathrm{g}}\right)$ of $117 \mathrm{~nm}$, with a geometric standard deviation $\left(\sigma_{\mathrm{g}}\right)$ of 1.7 , has been used to create a log-normal size distribution based on the average of 20 data points of fresh (no more than a few minutes old) smoke samples taken across several studies, compiled by Janhäll et al. (2010). This number distribution was converted to a volume distribution, normalised and, assuming a constant particle density, mapped to the eight MOSAIC size bins. The fraction of total aerosol emissions assigned to each bin is shown in Table 1.

Biomass burning events exhibit a strong diurnal cycle (Giglio, 2007). To approximate this diurnal variation in a model, a Gaussian distribution that peaks at a local time of around 15:00 LT (approximately 18:00 UTC over Brazil) is often used (Kaiser et al., 2009; Freitas et al., 2011). As a large landmass such as South America spans several time zones, for this study a local time $\left(t_{1}\right)$ for each emission point is calculated:

$t_{1}=t_{\mathrm{UTC}}+\frac{\mathrm{LON}}{15}$

where LON is the local longitude, in degrees, varying between -180 and $+180^{\circ}$. This is used to define a Gaussian function, $r\left(t_{1}\right)$, based on that used by Freitas et al. (2011), with a peak at 15:00 LT, defined such that the integral of $r\left(t_{1}\right)$ over $24 \mathrm{~h}$ is equal to 1 . This function modulates the magnitude of the emissions online within WRF-Chem. While Giglio (2007) suggest different diurnal cycles in different regions of Brazil based on different biomes, it was considered problematic to extrapolate from the regions used in the study to the biomes used in PREP-CHEM-SRC, and so the single diurnal cycle of Freitas et al. (2011) was retained.

\subsection{MACC-II boundary conditions}

Whilst regional models benefit from the increased resolution allowed by simulating a smaller area, they are dependent on boundary conditions from global model data sets for everything occurring outside the domain bounds. There is evidence for dust and BBA from Africa being transported across the Atlantic to Brazil (Rizzo et al., 2013; Brito et al., 2014). Amazonian fire plumes may also be transported out of and recirculated back into the domain. In order to avoid simulating the whole of the Atlantic and Africa, as was done by Freitas et al. (2009), it is necessary to be confident that the emission and long-range transport of these events is well captured by the boundary conditions.

The series of GEMS, MACC and MACC-II (Monitoring Atmospheric Composition and Climate - Interim Implementation; Hollingsworth et al., 2008; Flemming et al., 2013) projects have developed analysis, reanalysis and forecast products that use the MOZART- 3 chemical transport model (Emmons et al., 2010) with the ECMWF Integrated Forecast System (IFS), which has been expanded to integrate measurements of reactive gases (Stein et al., 2012), greenhouse gases and aerosol (Benedetti et al., 2009) in the ECMWF 4D-Var assimilation system (see Stein et al., 2012; Inness et al., 2013, and references therein). It calculates aerosol and reactive gas sources, chemical conversion, transport and deposition online, i.e. at each model time step (Morcrette et al., 2009; Stein et al., 2012). Daily biomass burning emissions of the Global Fire Assimilation System (GFAS) (Kaiser et al., 2009,2012 ) are also used. Using daily fire emissions and satellite assimilation gives better constraint on the chemical and aerosol loadings, providing more reliable boundary conditions. The mapping of MACC-II products to WRF-Chem species is detailed in Appendix A.

\section{Campaign description}

The SAMBBA aircraft campaign was based in Porto Velho, northern Rondônia. This is a region with extensive biomass burning owing to forest clearance. The ground measurement site was also located in the city, upwind of urban emissions. Nineteen flights were conducted between the 14 September and 3 October 2012, encompassing not only an extensive geographic area, but also differing synoptic conditions (see Darbyshire et al., 2015, for further details). Flights over the western regions encompassed two meteorological regimes as discussed in Brito et al. (2014), with Phase I (6 to 22 September 2012) representative of dry season conditions and Phase II (after 22 September) of the transition to the wet season. 
Table 3. Fractional apportionment of aerosol loadings from MACC-II model to eight MOSAIC size bins for initial and boundary conditions (Morcrette et al., 2009). Apportioning for MACC-II aerosol species are: black carbon (BC); organic aerosol (OA); sulfate aerosol (SULF); dust (DU); and sea salt (SS). This table uses the same MOSAIC dry particle diameters as Table 1.

\begin{tabular}{|c|c|c|c|c|c|c|c|}
\hline Bin 1 & Bin 2 & Bin 3 & Bin 4 & Bin 5 & Bin 6 & Bin 7 & Bin 8 \\
\hline \multicolumn{8}{|c|}{ BC, POM (hydrophobic and hygrophilic) and SULF } \\
\hline 0.0246 & 0.1475 & 0.3506 & 0.3321 & 0.1253 & 0.0187 & $1.1 \times 10^{-3}$ & $2.4 \times 10^{-5}$ \\
\hline \multicolumn{8}{|c|}{ SS Bin 1: 0.03-0.5 $\mu \mathrm{m}$} \\
\hline $\begin{array}{l}1.1 \times 10^{-3} \\
\text { SS Bin 2:0 }\end{array}$ & $\begin{array}{r}0.0312 \\
-5.0 \mu \mathrm{m}\end{array}$ & 0.3169 & 0.6502 & 0.0 & 0.0 & 0.0 & 0.0 \\
\hline $\begin{array}{c}0.0 \\
\text { SS Bin 3: } 5\end{array}$ & \multicolumn{6}{|c|}{ SS Bin 3: $5.0-20 \mu \mathrm{m}$} & 0.0 \\
\hline 0.0 & 0.0 & 0.0 & 0.0 & 0.0 & 0.0 & 0.0 & 0.5515 \\
\hline \multicolumn{8}{|c|}{ DU Bin 1: $0.03-0.5 \mu \mathrm{m}$} \\
\hline $\begin{array}{l}2.1 \times 10^{-5} \\
\text { DU Bin 2: }\end{array}$ & $\begin{array}{c}0.0023 \\
5-0.9 \mu \mathrm{n}\end{array}$ & 0.0928 & 0.9049 & 0.0 & 0.0 & 0.0 & 0.0 \\
\hline $\begin{array}{c}0.0 \\
\text { DU Bin 3: }\end{array}$ & \multicolumn{6}{|c|}{ DU Bin 3: 0.9-20 $\mu \mathrm{m}$} & 0.0 \\
\hline 0.0 & 0.0 & 0.0 & 0.0 & 0.0989 & 0.3736 & 0.3643 & 0.1415 \\
\hline
\end{tabular}

Conditions remained comparatively dry throughout in the eastern cerrado regions.

\subsection{Observational data sets}

In this study, WRF-Chem model results are compared against various remote sensing and ground-based data sets. The Tropical Rainfall Measuring Missions (TRMM) is a NASA project aiming to provide satellite derived estimates of tropical precipitation across the globe. The 3B42 product produces 3-hourly merged high quality, infrared and microwave precipitation estimates at $0.25^{\circ} \times 0.25^{\circ}$ resolution between $50^{\circ} \mathrm{N}$ and $50^{\circ} \mathrm{S}$ (Huffman et al., 2001, 2013).

The Moderate Resolution Imaging Spectrometer (MODIS) instrument, on board the two NASA satellites Aqua and Terra, provides measurements of AOD across a wide spectral range at $1.0^{\circ} \times 1.0^{\circ}$ (Remer et al., 2005). For this study, retrievals of AOD at $550 \mathrm{~nm}$ are used for verifying the model aerosol horizontal distribution. Overpasses over the study period and region of the globe were at approximately 03:00 and 15:00 UTC for the Terra satellite, and 06:00 and 18:00 UTC for the Aqua satellite. Model data was extracted at the these times when comparing against MODIS data. Over land, the MODIS AOD retrievals have an error of approximately 0.05 (Remer et al., 2005).

The Aerosol RObotic NETwork (AERONET) program is a ground-based deployment of around 100 sites, providing continuous observations of AOD at various wavelengths using the Version 2 Direct Sun Algorithm (Holben et al., 1998, 2001). AOD at $550 \mathrm{~nm}$ is estimated using measurements of
AOD at 675 and $440 \mathrm{~nm}$ and the Angström exponent. The data has been screened for clouds; only level 2.0 quality assured data is used for this study. Under cloud-free conditions, the error in measured AOD is approximately 0.01 (Holben et al., 2001). Data was retrieved for four sites over the central Brazilian region: Cuiabá $\left(15^{\circ} \mathrm{S}, 56^{\circ} \mathrm{W}\right)$; Ji-Paraná $\left(10^{\circ} \mathrm{S}\right.$, $\left.61^{\circ} \mathrm{W}\right)$; Porto Velho $\left(8^{\circ} \mathrm{S}, 63^{\circ} \mathrm{W}\right)$; and Rio Branco $\left(9^{\circ} \mathrm{S}\right.$, $\left.67^{\circ} \mathrm{W}\right)$.

\subsection{Instrument details}

The suite of aerosol instrumentation used on the FAAM BAe146 for this study is summarised in Table 4. The submicron nonrefractory aerosol composition was measured by an Aerodyne Research (Billerica, MA, USA) compact Time of Flight Aerosol Mass Spectrometer (cToF-AMS), as described by Drewnick et al. (2005), and Canagaratna et al. (2007), and for FAAM operation by Morgan et al. (2009). For speciated mass loadings, detection limits are approximately $40 \mathrm{ng} \mathrm{m}^{-3}$ for organics (Drewnick et al., 2009), whilst combined measurement uncertainties are approximately $30 \%$ (Bahreini et al., 2009; Middlebrook et al., 2012).

The Single Particle Soot Photometer (SP2), developed by Droplet Measurement Technologies (Boulder, CO, USA), was used to measure number and mass concentrations of refractory black carbon (rBC). Its operating principles are described in Stephens et al. (2003) and Baumgardner et al. (2004), with its utilisation onboard FAAM summarised by McMeeking et al. (2010). For reported mass loadings, the 
Table 4. Table of instrumentation used during SAMBBA flights B731 (14 September 2012), B734 (18 September 2012), B739 (23 September 2012) and B742 (27 September 2012). The coverage of each instrument for each flight is indicated by the categories: Full (> $80 \%$ coverage); Partial (between 80 and $30 \%$ ); or Insufficient (<30\%). For details of instruments see text in Sect. 4.2. Mass and number mixing ratios given per unit volume at standard temperature and pressure $\left(\mathrm{sm}^{-3} \mathrm{or} \mathrm{scm}^{-3}\right)$.

\begin{tabular}{|c|c|c|c|c|c|c|c|}
\hline Instrument & Measurement & Units & Temporal resolution & B731 & B734 & B739 & B742 \\
\hline SP2 & $\mathrm{BC}$ & $\mu \mathrm{g} \mathrm{sm}^{-3}$ & $1 \mathrm{~s}$ & Insufficient & Full & Full & Full \\
\hline cToF-AMS & POM & $\mu \mathrm{g} \mathrm{sm}^{-3}$ & $\begin{array}{l}\approx 30 \mathrm{~s} \text { in level runs } \\
\approx 10 \mathrm{~s} \text { during profiles }\end{array}$ & Partial & Full & Full & Full \\
\hline AL5002 VUV & $\mathrm{CO}$ & ppbv & $1 \mathrm{~s}$ & Full & Full & Full & Full \\
\hline Dry nephelometer & $b_{\text {scat }}$ & $1 \mathrm{~s}$ & $\mathrm{~km}^{-1}$ & Partial & Full & Full & Full \\
\hline PSAP & $b_{\mathrm{abs}}$ & $\mathrm{km}^{-1}$ & $25-30 s$ & Partial & Full & Partial & Partial \\
\hline SMPS & $\begin{array}{l}\text { Number distribution } \\
(20-350 \mathrm{~nm})\end{array}$ & $\mathrm{scm}^{-3}$ & $\approx 60 \mathrm{~s}$ & Partial & Full & Insufficient & Full \\
\hline GRIMM & $\begin{array}{l}\text { Number distribution } \\
(0.3-20 \mu \mathrm{m})\end{array}$ & $\mathrm{scm}^{-3}$ & $\approx 6 \mathrm{~s}$ & Full & Full & Full & Full \\
\hline $\mathrm{CCNc}$ & $\mathrm{CCN}$ concentration & $\mathrm{scm}^{-3}$ & $1 \mathrm{~s}$ & Full & Full & Insufficient & Full \\
\hline
\end{tabular}

measurement uncertainty is approximately $30 \%$ (Schwarz et al., 2008; Shiraiwa et al., 2008).

Aerosol total scattering coefficients were measured by a TSI Inc (St. Paul, MN, USA) 3-wavelength integrating nephelometer (Anderson et al., 1996), with standard corrections applied for angular truncation and non-Lambertian light source errors (Anderson and Ogren, 1998; Müller et al., 2011), and for relative humidity, using the humidification factors defined for Porto Velho haze in Kotchenruther and Hobbs (1998). A Radiance Research Particle Soot Absorption Photometer (PSAP) measured the aerosol absorption coefficient at $567 \mathrm{~nm}$ and standard corrections for spot size, flow rate and scattering particles were applied following Bond et al. (1999), Ogren et al. (2010) and Turnbull (2010).

Aerosol number-size distributions were measured across the $20 \mathrm{~nm}$ to $20 \mu \mathrm{m}$ range by a Scanning Mobility Particle Sizer (SMPS, 20 to $350 \mathrm{~nm}$; Wang et al., 1990) and a GRIMM model 1.129 Optical Particle Counter (OPC, 0.3 to $20 \mu \mathrm{m}$; Heim et al., 2008). Note that the GRIMM data used in this paper is uncorrected for the minor impact of refractive index. A Droplet Measurement Technologies Inc. (DMT) dual column Cloud Condensation Nuclei counter (CCNc) was used to measure $\mathrm{CCN}$ concentrations with an approximate measurement error of $7 \%$. The operating principles are outlined in Roberts and Nenes (2005), whilst its utilisation onboard FAAM is described in Trembath (2013).

The aerosol instrumentation onboard FAAM samples through a Rosemount inlet which, despite suffering known artefacts for larger particles, is adequate for the submicron size range presented here (Trembath, 2013). All measured data have been converted into units of standard temperature and pressure. Further details on instruments, calibration protocols and quality assurance of data are provided in Darbyshire et al. (2015) and Morgan et al. (2015). Carbon monoxide (CO) was measured using an Aero-Laser AL5002
VUV resonance fluorescence gas analyser. The raw $\mathrm{CO}$ was calibrated in-flight.

From each instrument time series the influence of fresh plumes was removed, as to isolate the regional haze measurements, following the plume identification technique discussed in Darbyshire et al. (2015).

\subsection{Model setup}

For this study a modified version of WRF-Chem Version 3.4.1 has been used. A single lambert projection domain with $226 \times 196$ grid cells, at a horizontal spacing of $25 \mathrm{~km}$, covers most of South America. Forty-one vertical levels are used, spaced to give greater resolution in the boundary layer. Global land use data of $1 \mathrm{~km}$ resolution was provided by the United States Geological Survey (USGS), with vegetation maps updated for the Brazilian Legal Amazon Region with the PROVEG data set updated for the year 2000 (Sestini et al., 2003; Freitas et al., 2011; Beck et al., 2013). Figure 1 shows the model domain with the USGS land use categorisations.

The chemistry options used were the Kinetic PreProcessor (KPP; Damian et al., 2002) compiled version of CBM-Z (Zaveri and Peters, 1999) with 8-bin MOSAIC aerosol and aqueous chemistry (Zaveri et al., 2008). The Maxwell-Garnett mixing-rule approximation was used to calculate optical properties of the aerosol, linked with the RRTMG longwave and shortwave radiation parameterisation (Mlawer et al., 1997; Pincus et al., 2003).

The physical parameterisations used for this study are summarised in Table 5. The non-local Yonsai University (YSU) planetary boundary layer (PBL) scheme (Hong et al., 2006) defines the boundary layer height as the mixed layer height:

$h=R i_{\mathrm{c}} \frac{\theta_{\mathrm{va}}|U(h)|^{2}}{g\left[\theta_{\mathrm{v}}(h)-\theta_{\mathrm{s}}\right.}$, 


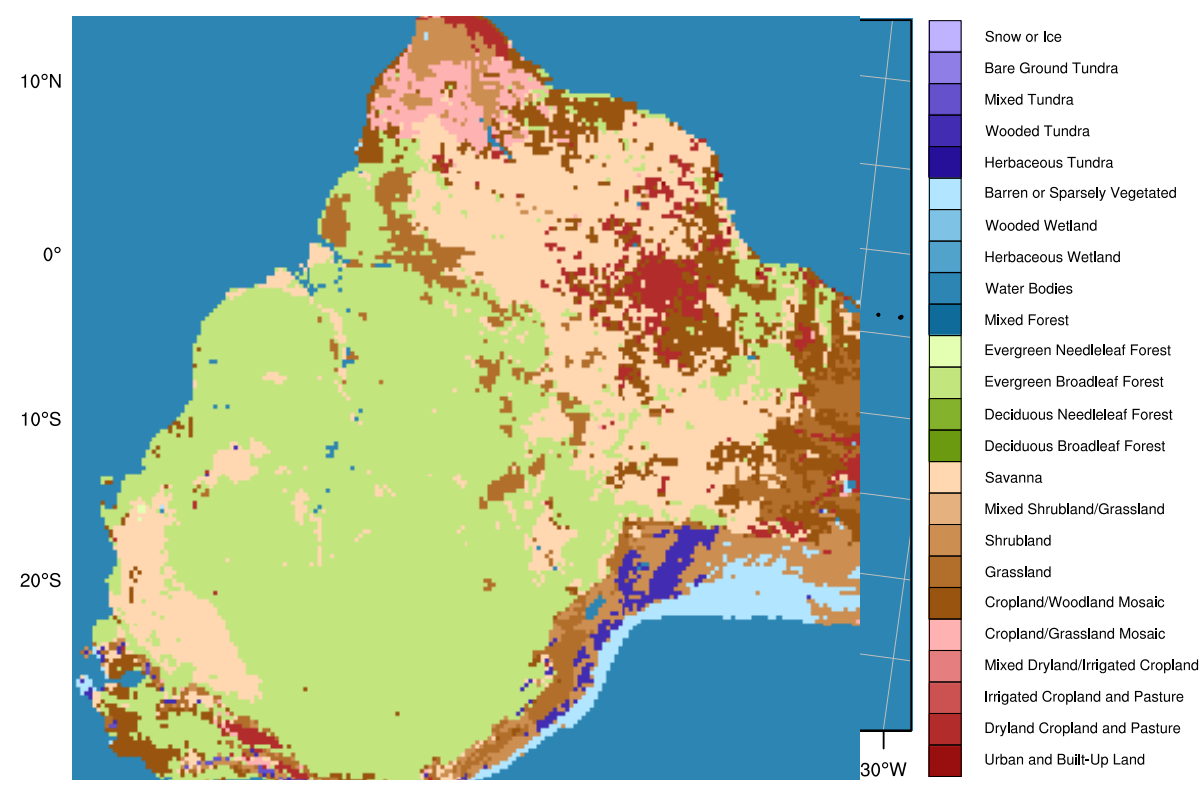

Figure 1. Map of domain used for study, at $25 \mathrm{~km}$ horizontal grid spacing with lambert projection. Coloured by 24 USGS land use categories. The southern Amazon, coloured green, is the main region of deforestation burning, corresponding to the West-central Brazilian states and northern Bolivia. The East-central Brazilian states, coloured pale-brown, are the main regions of cerrado burning.

Table 5. Summary of physical parameterisations used in WRF-Chem model runs.

\begin{tabular}{lll}
\hline Process & WRF-Chem Option & Reference \\
\hline Microphysics & Morrison 2-moment & Morrison et al. (2005) \\
Aerosol activation & Abdul-Razzak and Ghan & Abdul-Razzak and Ghan (2002) \\
Cumulus parameterisation & Grell 3-D & Grell and Devenyi (2002) \\
Planetary boundary layer & Yonsai University (YSU) & Hong et al. (2006) \\
Surface layer & MM5 surface-layer similarity & Zhang and Anthes (1982) \\
Land-surface model & Unified NOAH land-surface & Ek et al. (2003) \\
Longwave radiation & RRTMG & Mlawer et al. (1997) \\
Shortwave radiation & RRTMG & Pincus et al. (2003) \\
\hline
\end{tabular}

where $R i_{\mathrm{c}}$ is the critical bulk Richardson number $(=0.5)$, $U(h)$ is the horizontal wind speed at $h, \theta_{\mathrm{v}}$ is the virtual potential temperature, $\theta_{\mathrm{va}}$ is the virtual potential temperature at the lowest model level and $\theta_{\mathrm{S}}$ is the temperature at the surface. It is solved iteratively with $\theta_{\mathrm{s}}$, as described by Hong et al. (2006). The average mixed layer height at 17:00 LT was found to be $1873 \pm 541 \mathrm{~m}$ over forested regions and $2912 \pm 301 \mathrm{~m}$ over cerrado regions; approximately 800 and $1300 \mathrm{~m}$ higher, respectively, than the values given by Fisch et al. (2004) for forest and pasture sites in dry season Amazonia.

The operational, deterministic (high-resolution) 1 day forecasts of the European Centre for Medium-Range Weather Forecasts (ECMWF) http://www.ecmwf.int/ were used to drive the meteorology. Long-term running options, for updating sea-surface temperature and other fields, were activated. Chemical boundary conditions were taken from MACC-II. The MACC-II system is an extension of
ECMWF's integrated forecasting system (IFS) used for operational forecasting, which is run at a lower resolution of T255 instead of T1279. Since feedback from aerosols on the meteorology is disabled, the meteorological fields are virtually identical to the operational meteorological forecasts, albeit with lower resolution. This ensures consistency between the chemical and meteorological boundary conditions in this study.

PREP-CHEM-SRC v1.4 was used to generate anthropogenic and biomass burning emission maps. Anthropogenic emissions of $\mathrm{CO}, \mathrm{SO}_{2}, \mathrm{NO}_{\mathrm{x}}, \mathrm{NH}_{3}$ and NMVOCs are derived from the Emissions Database for Global Atmosphere Research (EDGAR) version 4.02005 emissions at $0.1^{\circ} \times$ $0.1^{\circ}$ resolution (Olivier et al., 2002). Primary anthropogenic aerosol emissions of $\mathrm{BC}$ and $\mathrm{OC}$ are from from the Goddard Chemistry Aerosol Radiation and Transport (GOCART) model databases $1^{\circ} \times 1^{\circ}$ resolution (Freitas et al., 2011). Burning of residue in fields, residue and dung used as bio- 
fuels, fuelwood and charcoal burning was included using the Yevich and Logan (2003) inventory, applied with the Andreae and Merlet (2001) emission factors. Modifications to PREP-CHEM-SRC were made to convert OC into POM for all anthropogenic emissions with a factor of 1.6 (based on Turpin and Lim, 2001) and to include $\mathrm{NH}_{3}$ emissions. Biogenic emissions were calculated "online" using the Model of Emissions and Gases and Aerosols from Nature (MEGAN) version 2 (Guenther et al., 2006).

Fire emissions were calculated using the 3BEM emissions inventory. Two emissions scenarios have been used for this study:

- Standard 3BEM emissions: default $A_{\text {fire }}=22.8$ ha, $S_{\text {fire }}=A_{\text {fire }} \cdot f_{x}=1.3$.

- Modified 3BEM emissions. $A_{\text {fire }}$ and $S_{\text {fire }}$ depend on vegetation type, as described in Table 2. $f_{x}=5$.

Figure 2 shows horizontal maps and vertical cross-sections of the plume-risen fire emissions for the two scenarios. The horizontal distribution is similar for both scenarios. There is a significant reduction in average emissions in the second phase of the campaign, along with a relative shift of emissions east towards drier, cerrado regions. The vertical profiles of emissions show much greater differences between the two scenarios. The cerrado fires, predominantly east of $50^{\circ} \mathrm{W}$, have peak injection heights of just above $4 \mathrm{~km}$ in both emissions scenarios. The western fires, which are predominantly tropical forest biomes, peak between 5 and $12 \mathrm{~km}$ in the standard emission scenario, and $3-6 \mathrm{~km}$ in the modified emission scenario, despite the lower boundary layer over the forest. While the injection height is lower in the modified emissions scenario, it is still higher than what is usually reported. For example, in a global review of MISR fire plume height retrievals, Sofiev et al. (2013) show the majority of daytime August wildfire plumes are below $2.5 \mathrm{~km}$ in altitude over Amazonia.

The injection height shows a strong diurnal cycle, reflecting the cycle of fire activity that follows a fixed parameterisation in this study. Flaming emissions are injected just above ground at night and the early morning/late evening. Over the course of the day, as the atmosphere becomes more unstable, the injection height for each fire will typically make a discontinuous "jump" into the higher levels of the atmosphere as and when the convection is triggered within the parameterisation. The time and height of this "jump" varies from day-to-day, depending on the ambient meteorological conditions, and is highly non-linear. This behaviour can be observed in the 3-D animation of model CO over the campaign rendered using VAPoR (Clyne et al., 2007) included in the Supplement.

The scenarios were run from 1 September to 1 October 2012, encompassing all the flights of interest. Between 1 and 11 September 2012 the model was spun up with meteorological nudging to build reasonable background aerosol fields in the model. From 11 September to 1 October, meteorological fields were reset from the ECMWF data every 2 or 3 days. Nudging was turned off for the later periods so as not to interfere with aerosol radiative feedbacks (to be discussed in more detail in future studies).

\section{Results and analysis}

The purpose of this study is to characterise the aerosol population and compare with measurements. The aim is to develop as accurate a picture as possible of the horizontal and vertical distribution, size distribution and composition.

Prior to investigating the aerosol carried by the model, we will establish that it represents the meteorological fields with a reasonable level of accuracy. Aerosol loss processes are dominated by wet deposition, and the injection height of the flaming emissions will depend partly on the vertical profile of the atmosphere and wind speed in the column. We will then proceed into more in-depth characterisation of the aerosol, firstly over the whole period of the campaign against remote satellite measurements and long-term AERONET sites, then with more detailed in situ measurements from the SAMBBA aircraft campaign.

\subsection{Verification of meteorology and stability profile of atmospheric column}

Figure 3 shows maps of average precipitation over the two phases of the campaign. The two panels on the left are derived from the TRMM $3 \mathrm{~B} 42$ product of 3-hourly gridded precipitation at $0.25^{\circ} \times 0.25^{\circ}$ resolution (Huffman et al., 2001, 2013). The broad trends and magnitude of precipitation are well represented in the model. The average daily precipitation over South America in Phase I is significantly lower than in Phase II and largely concentrated in the north-west. In Phase II, the average rate is much higher and the precipitation spreads much further into the central states. However, some fine detail is missed in the model and the precipitation does not spread as far east as the TRMM data suggests. For example, there are several instances of storms in phase II between 45 and $50^{\circ} \mathrm{W}$ not reproduced in the model.

Precipitation trends over the course of the campaign had a strong impact on the BBA concentrations in the western regions, because both increased precipitation reduced the number of fires and increased the level of wet deposition in the biomass burning regions. Phase I was characterised by the accumulation of regional haze, with some localised removal events. Widespread precipitation throughout Phase II largely washed out the accumulated haze, but continued burning maintained a polluted haze, albeit relatively clean compared to Phase I. Throughout, conditions remained dry in the eastern states.

Drop-sondes were used during the SAMBBA flights to measure temperature, moisture content and wind speed in the 

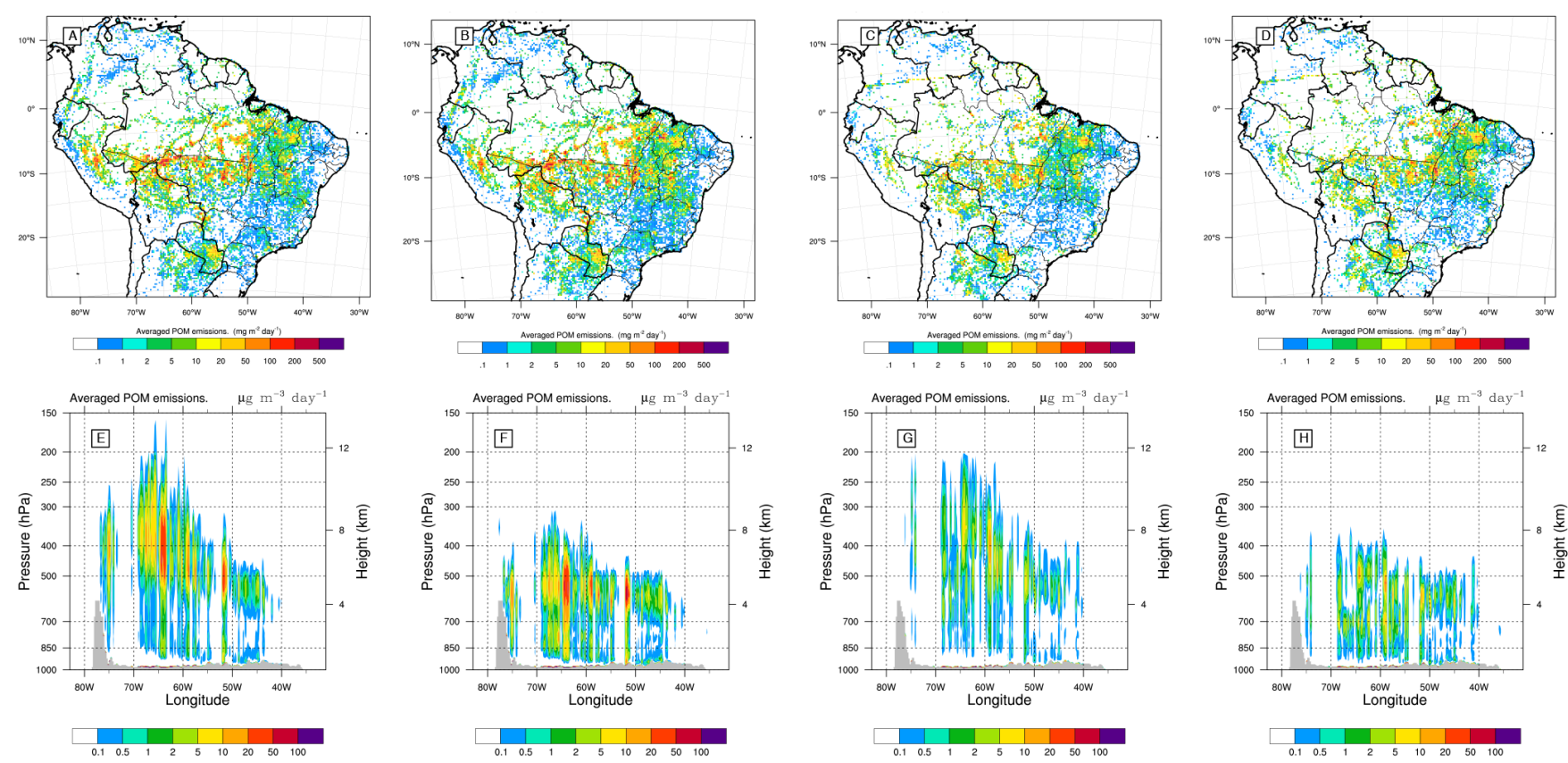

Figure 2. Emissions of organic aerosol (OA) over the course of the campaign. Panels (a-d) are maps of emissions, showing total emissions in the atmospheric column $\left(\mathrm{mg} \mathrm{m}^{-2} \mathrm{day}^{-1}\right)$. Panels $(\mathbf{e}-\mathbf{h})$ are vertical profiles of emissions through a transect along $9^{\circ} \mathrm{S}\left(\mu \mathrm{g} \mathrm{m}{ }^{-3} \mathrm{day}^{-1}\right)$. Panels (a), (b), (e) and (f) show averaged emissions over Phase I of the campaign (6-22 September 2012). (c), (d), (g) and (h) are averaged over Phase II (23-30 September). Panels (a), (c), (e) and (g) are for the traditional 3BEM emissions. Panels (b), (d), (f) and (h) are for the modified emissions, using smaller fire size and burned area depending on vegetation type as described in Table 2.

Table 6. Table of mean, spatial standard deviation and centred Pearson's product-moment correlation coefficient; comparing AOD at 550 nm from the two WRF-Chem emissions scenarios with the combined MODIS Terra and Aqua satellite data. Data used same as to plot Fig. 5.

\begin{tabular}{lccccccc}
\hline \multirow{2}{*}{ Data set } & \multicolumn{3}{c}{ Phase I } & & \multicolumn{3}{c}{ Phase II } \\
\cline { 2 - 3 } \cline { 7 - 8 } & Mean & $\begin{array}{c}\text { Standard } \\
\text { deviation }\end{array}$ & $\begin{array}{c}\text { Correlation } \\
\text { coefficient }\end{array}$ & & Mean & $\begin{array}{c}\text { Standard } \\
\text { deviation }\end{array}$ & $\begin{array}{c}\text { Correlation } \\
\text { coefficient }\end{array}$ \\
\hline MODIS & 0.321 & 0.190 & NA & & 0.221 & 0.131 & NA \\
Standard 3BEM & 0.355 & 0.129 & 0.678 & & 0.285 & 0.117 & 0.623 \\
Modified 3BEM & 0.381 & 0.155 & 0.732 & & 0.286 & 0.131 & 0.591 \\
\hline
\end{tabular}

atmospheric column. Skew-T plots from drop-sondes from four flights are compared with model data in Fig. 4. Skew$\mathrm{T}$ plots for all other drop-sondes made during the SAMBBA campaign can be seen in the Supplement. The model generally represents the coarse structure and wind direction of the column well. However it fails to reproduce some of the fine detail. This is unsurprising given the relatively coarse vertical and horizontal resolution of the model. The fit for the temperature profile is better than for the dewpoint profile, with several examples of stratification in the dewpoint profile observed in the flights not seen in the model. For example between 850 and $700 \mathrm{hPa}$ in flight B737 (Fig. 4c), the model significantly overestimates the moisture content of the atmosphere. It was observed on the SAMBBA flights that these dewpoint inversions would cap aerosol transport, forming distinct layers. This is a phenomena we are unlikely to reproduce in the model. The top of the modelled boundary layer, inferred from the lowest inversion in the temperature profile, is generally close to that observed in the measurements, but not as clearly defined or strong.

\subsection{Horizontal distribution and optical properties of aerosol - comparison with remote sensing data}

Figure 5 shows the averaged AOD at $550 \mathrm{~nm}$ over the two phases of the campaign. The panels on the left show AOD from combined MODIS Aqua and Terra satellites, whilst the centre and right panels show AOD from the model runs using standard 3BEM emissions and the modified emission setup respectively.

Phase I is characterised by a build-up of BBA, forming a large regional haze with high AOD over much of central 

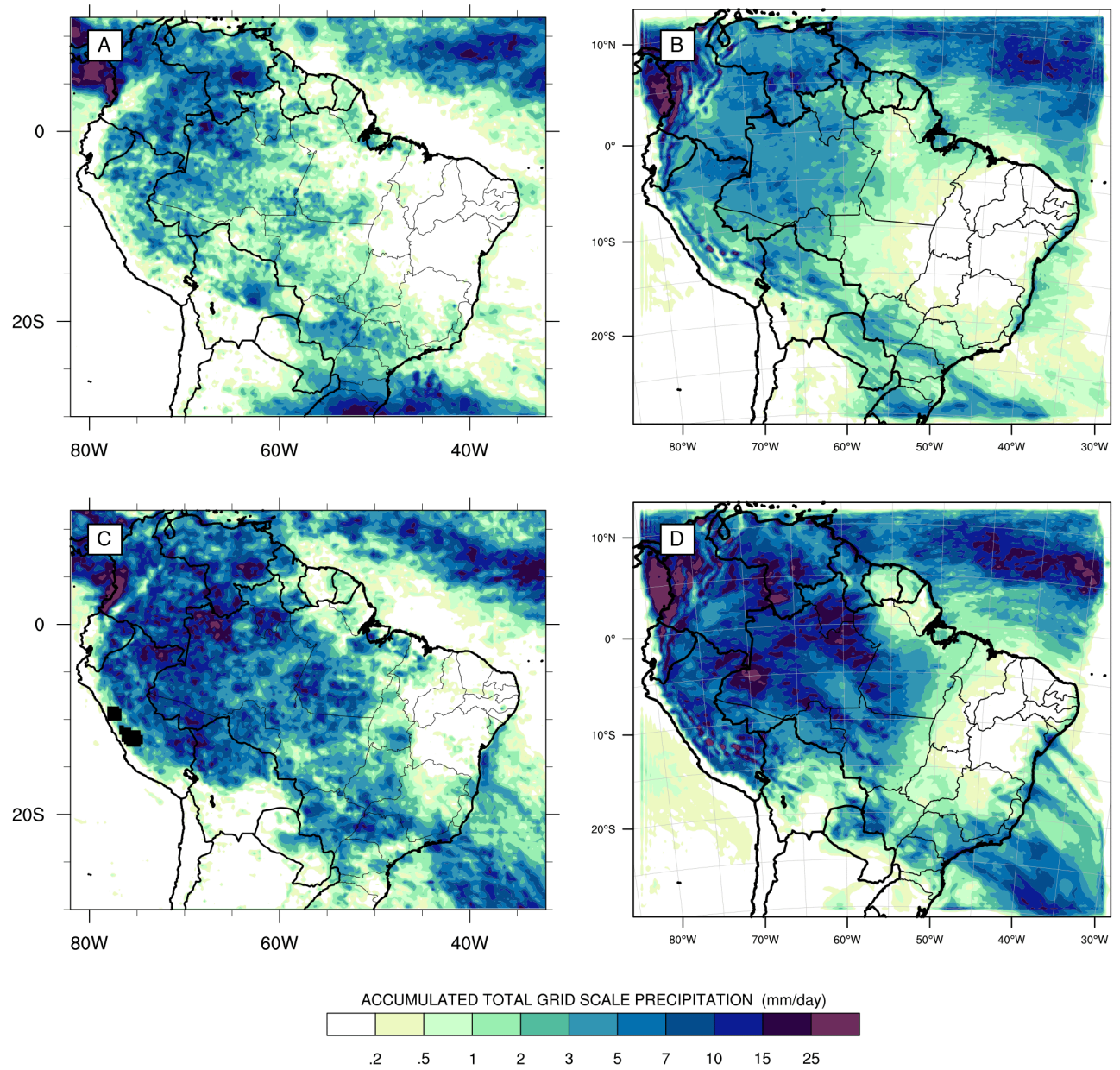

Figure 3. Maps of averaged precipitation $\left(\mathrm{mmday}^{-1}\right)$. (a and c) are derived from the TRMM 3B42 satellite product (Huffman et al., 2001, 2013). (b and d) from WRF-Chem model runs. (a and b) for Phase I (6-22 September 2012), (c and d) over Phase II (23-30 September).

South America. The magnitude of the AOD is well captured in the model, and is closest to that observed by the satellites in the modified emission scenario. However, the distribution is displaced: the highest AODs observed by the satellites are in central Mato Grosso state, around $55^{\circ} \mathrm{W}$ and $15^{\circ} \mathrm{S}$, while in both model runs it is in Rondônia state further to the northwest, particularly around a cluster of fires at $64^{\circ} \mathrm{W}$ and $10^{\circ} \mathrm{S}$. This is the location of the greatest fire emissions in both emission products, as shown in Fig. 2. As this does not show as strongly in the satellite data, emissions are presumably too strong at this location.

During Phase I, both model runs show a significant proportion of BBA transported west not observed by the satellite AOD measurements in Fig. 5. This is due to a combination of both a greater proportion of the emissions originating in western states/forest biomes and a greater proportion of the aerosol being in the upper levels of the troposphere. Figure $4 \mathrm{a}$ and $\mathrm{b}$ show easterly winds in the free troposphere and northerlies in the boundary layer over these flights. During Phase II, both model and satellite data show reduced AOD over much of the domain. The satellite measurements show a large reduction in BBA over Rondônia, but significant AOD in the north-eastern states where most fires are cerrado. In the model runs, there is an eastward shift compared to Phase I, particularly in the modified emission scenario, but AOD in the eastern regions is still lower than that observed by the satellites. Mean, standard deviation and spatial correlation coefficients of AOD for Phases I and II are given in Table 6. Compared to the standard 3BEM emissions scenario, the modified emission scenario shows higher mean AOD in both Phases, stronger correlation in Phase I, but weaker correlation in Phase II.

Figure 6 shows the time series of AOD at $550 \mathrm{~nm}$ measured at four of the AERONET sites marked in Fig. 5, including measurements from overpasses of the MODIS Aqua and Terra satellites. The panels on the left show the standard 3BEM emissions and the panels on the right are for modified emissions. There is little difference in AOD simulated at these sites between the two emission scenarios. With the exception on the Cuiabá site, the model replicates the build-up 

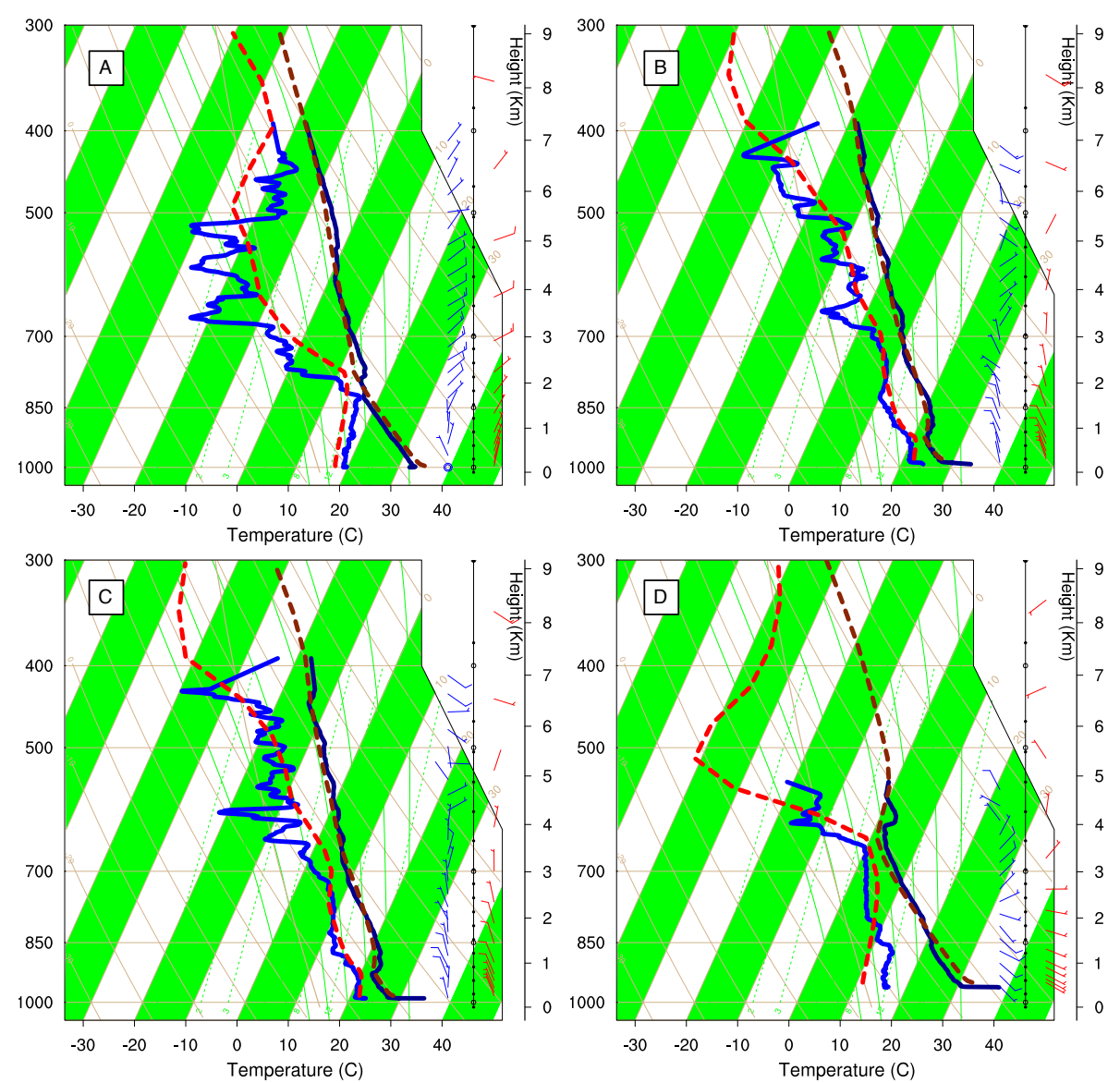

Figure 4. Skew-T plots comparing data from sondes dropped during SAMBBA flights with column data extracted from the WRF-Chem model at the time and place of the drop-sonde. Drop-sondes were taken from (a) B731 (14 September, dropped at 16:02:28 UTC); (b) 734 (18 September, 12:46:52 UTC); (c) B734 (18 September, 12:56:53 UTC); and (d) B742 (27 September, 13:36:59 UTC). The red dashed lines are from WRF-Chem model data; the blue solid lines are from drop-sonde. The bright coloured lines on the left show dewpoint $\left({ }^{\circ} \mathrm{C}\right)$; the dark coloured lines on the right show temperature $\left({ }^{\circ} \mathrm{C}\right)$. The barbs on the right of the plots show wind direction from drop-sonde (blue) and model (red).

of aerosol and AODs in the first half of the campaign well (although it should be noted that $f_{x}$ was tuned to be able to represent the magnitude of AODs in this part of the campaign). The Cuiabá site is likely too low in the model because this region is more dominated by cerrado fires, whereas the other sites have a greater proportion of forest fires nearby.

In Phase II of the campaign, the model runs overestimate the AOD over every AERONET site evaluated against. It proved to be a challenge to find a suitable scaling factor to enable a large enough build-up of AOD in the first half of the campaign without "overshooting" in Phase II. This may be due to the model not washing out aerosol as efficiently as it should, the emissions not decreasing in intensity enough in the second half, or a combination of these factors.

\subsection{Comparisons with in situ aircraft measurements}

\subsubsection{Vertical distribution of $\mathrm{CO}$ and BBA}

In this section of the paper, we will be comparing model results with in situ measurements of aerosol and aerosol optical properties from flights conducted during the SAMBBA campaign. The remainder of the analysis will focus on four flights as case studies: B731, B734, B739 and B742 on 14, 18, 23 and 27 September 2012 respectively. The instrument coverage of these flights is summarised in Table 4. These flights were selected as they extensively sampled the regional haze across the range of environments and meteorological conditions encountered during the campaign, with near complete instrument coverage. Flights B731, B734, B739 sampled the regional haze in Rondônia state, characterised by cleared and pristine forest, whilst B742 sampled over Tocantins state in the cerrado (savannah-like) environment. All aerosol data from the model has been summed over bins where $D_{\mathrm{p}}$ is 

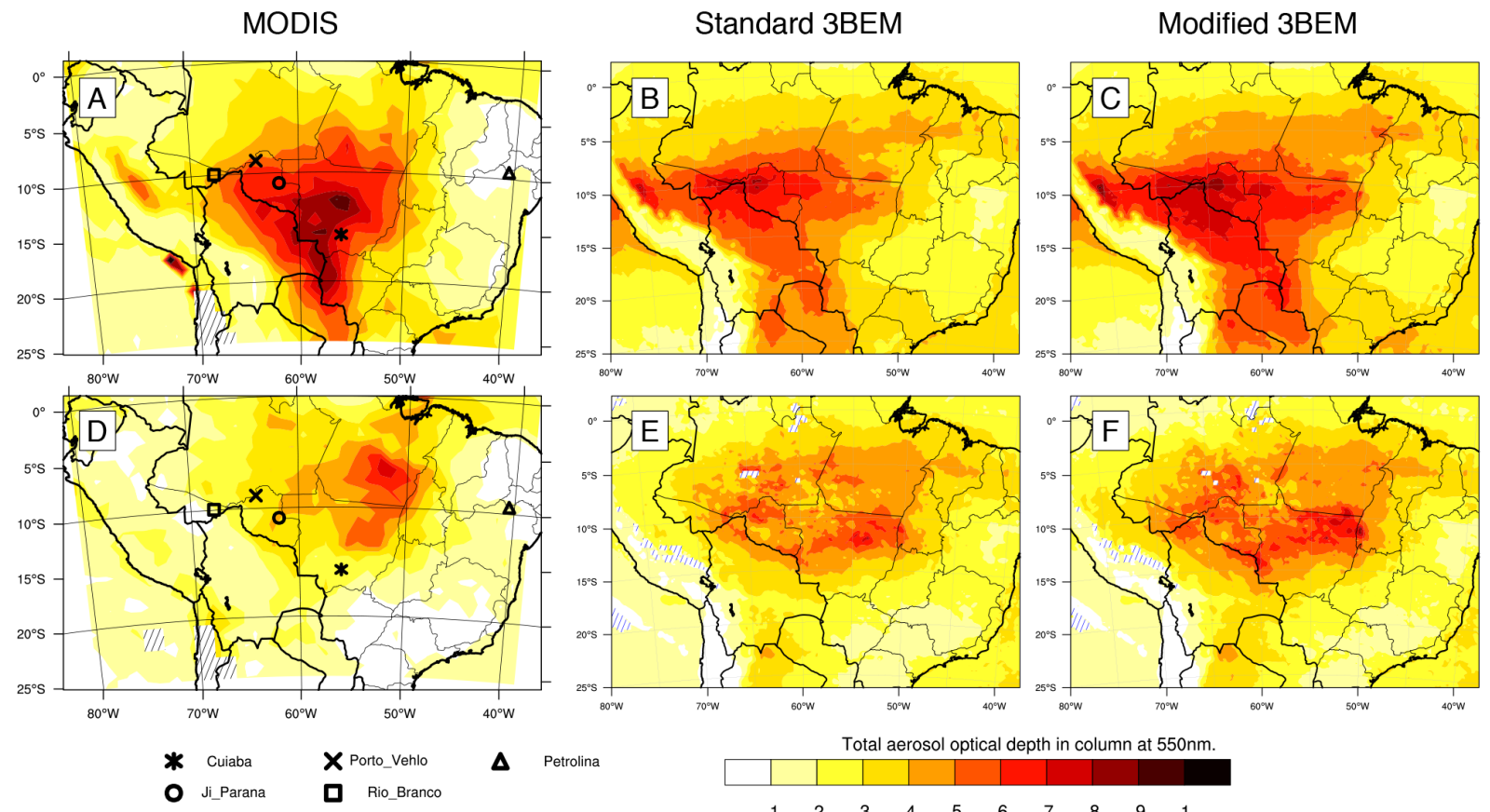

$\begin{array}{llll}\text { * Cuiaba } & \boldsymbol{X} \text { Porto_Vehlo } & \boldsymbol{\Delta} & \text { Petrolina } \\ \boldsymbol{0} & \text { Ji_Parana } & \boldsymbol{\square} \text { Rio_Branco } & \end{array}$

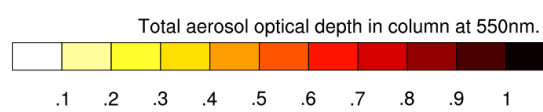

Figure 5. Horizontal maps of column AOD at $550 \mathrm{~nm}$, comparing the WRF-Chem model runs against MODIS measurements onboard the Aqua and Terra satellites. WRF-Chem data was extracted at times close to the overpass times of the Aqua and Terra satellites over South America: (a, b and $\mathbf{c}$ ) for the first phase of the campaign (6-22 September 2012); (d, e and f) averaged over the second phase of the campaign (23-30 September). (a and d) combined Aqua and Terra satellite data; (b and e) from model runs using standard 3BEM emissions; (c and f) using modified 3BEM emissions. The symbols in panels (a) and (d) signify the location of AERONET sites operational during the campaign period.

$<1 \mu \mathrm{m}$ (defined as all bins $1-4$ and $67.8 \%$ of bin 5) and converted to standard temperature and pressure units $\left(\mu \mathrm{g} \mathrm{sm}^{-3}\right)$ for comparison with submicron flight measurements.

The paths of the flights used in this study are shown in Fig. 7. Following a profile ascent out of the host airport (Porto Velho for B731, B734 and B739, Palmas for B742), the aircraft travelled to the region of interest at high altitude (7-8 kma.s.1.), before descending to near surface via a stack of straight and level runs at altitudes above and within the boundary layer. Flight B739 was a slight exception to this pattern, with only a brief period at high altitude, and without the straight and level runs in the stacked formation. Near surface, flights B739 and B742 sampled extensive small plumes in the area, resulting in non-uniform flight patterns. All flights then returned either at high altitude (B731, B734) or high within the boundary layer (B739, B742), before profile descent back to base. Each flight therefore had a number of profiles and straight and level runs at multiple altitudes, providing a comprehensive characterisation of the haze in the region sampled. The boxes around each of the flight paths in Fig. 7 show the area averaged over when calculating the statistics from the model when carrying out the comparisons.

Figure 8 shows vertical profiles of $\mathrm{CO}, \mathrm{POM}$ and scattering coefficient at $550 \mathrm{~nm}\left(b_{\text {scat }}\right)$. CO is used as a relatively inert tracer, largely unaffected by precipitation or wash-out.
POM is shown and compared with AMS organics data as it makes up the dominant fraction of the total aerosol budget. Finally, $b_{\text {scat }}$ is used to show the optical depth of the aerosol. $b_{\text {scat }}$ is used rather than $b_{\text {ext }}$ to avoid additional measurement uncertainty by the addition of $b_{\text {abs }}$ (Bond et al., 2013). The flight data is limited by never flying above $8 \mathrm{~km}$ altitude. However, as a significant portion of the plume-rise emissions in the standard 3BEM case are emitted above $8 \mathrm{~km}$ (see Fig. 2), the profiles from the model runs are plotted up to $12 \mathrm{~km}$. This measurement evaluation is an improvement over Longo et al. (2010), where the plume-risen emissions were compared against flights that did not fly above $4 \mathrm{~km}$ and comparisons were only made with $\mathrm{CO}$.

B731 coincided with the end of a long build-up of aerosol in Rondônia before it was washed out during the progression into the wet season and had some of the highest measurements of aerosol in the campaign. Both model scenarios under-predict CO and POM within the boundary layer and over-predict above the boundary layer. The flights show the majority of $\mathrm{CO}$ and aerosol are in the lower $2 \mathrm{~km}$ of the troposphere, with a steep drop off above this. Both model runs show a secondary peak in aerosol above the boundary layer, between $4-5 \mathrm{~km}$ in the updated emissions scenario and around $7 \mathrm{~km}$ using the standard 3BEM emissions. In both model runs, too large a proportion of the emissions are being 

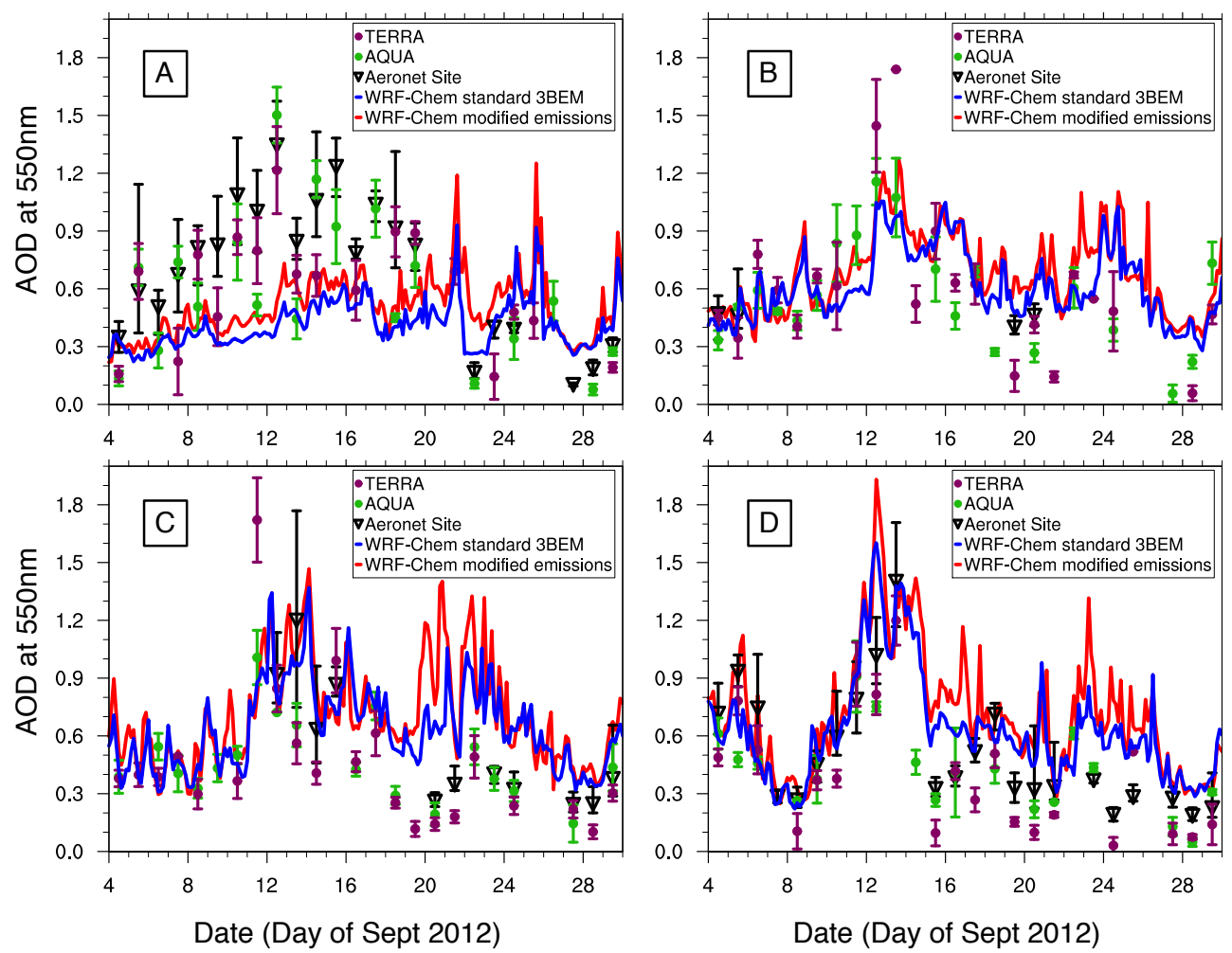

Figure 6. Time series of aerosol optical depth at $550 \mathrm{~nm}$ at four AERONET sites between 4 September and 1 October 2012: (a) at Cuiabá; (b) at Ji Paraná; (c) at Porto Velho; and (d) at Rio Branco. Blue triangles show AERONET site daily measurements, with bars indicating range in values over the day. Purple and green circles indicate measurements from overpasses of TERRA and AQUA satellites respectively, with bars indicating error range. Blue lines show data from WRF-Chem model simulations using standard 3BEM emissions. Red lines show data from WRF-Chem model using the modified emissions.

emitted above the boundary layer. The same elevated peak can be observed in $b_{\text {scat }}$, although it decreases faster above the boundary layer than POM. This is because POM is in units at standard temperature and pressure and independent of altitude, while $b_{\text {scat }}$ is related to the absolute density of particles and decreases exponentially with altitude. $b_{\text {scat }}$ is therefore dominated by aerosol in the boundary layer in both flight and model.

By the time of flight B734, significant precipitation had occurred over Rondônia, reducing the aerosol loadings in both model and measurements. The flight is also sampling a different region of Rondônia. $\mathrm{CO}$ in the boundary layer is also lower, implying reduced fire emissions. Below $4 \mathrm{~km}$, flight $\mathrm{CO}$ and POM are similar to the modified emissions scenario. Above $4 \mathrm{~km}, \mathrm{CO}$ remains elevated in both measurement and model. POM sharply decreases in the flight data, while in the model it is clear that the POM has been emitted at the same height as the $\mathrm{CO}$ and follows a similar profile. The lack of observed POM at the same altitude as CO implies either the wash-out processes are not being well represented in the model, both $\mathrm{CO}$ and POM are being emitted at altitude in an unrealistic fashion with less of a negative impact on $\mathrm{CO}$, or the flight is measuring a source of $\mathrm{CO}$ that does not have much associated POM.

Flight B739 was conducted at the start of Phase II, by which time the majority of accumulated aerosol in the western states had been washed out. During this flight, there were large stratocumulus clouds and significant convection over the region. The increased soil moisture after previous days precipitation resulted in a larger fraction of smouldering fires. Given the limitations of the model setup, we would expect this flight to be the most challenging of the case studies for the model. High concentrations of $\mathrm{CO}$ and slightly elevated POM in the lowest $\mathrm{km}$ of the boundary layer are observed, but these fresh emissions have not become well mixed at the time of flights. Aside from that, the measured atmosphere is relatively clean compared to the earlier flights. The standard 3BEM emission scenarios is close to the measurements for $\mathrm{CO}$, at least up to $6 \mathrm{~km}$ altitude, whereas the modified emission scenario has too much $\mathrm{CO}$. However, both model scenarios over-predict POM in and above the boundary layer. The elevated peak in POM and CO in the model is much higher during this period, especially in the standard 3BEM case where it is above where the flights can observe. While the existence of this layer cannot be ruled out, from the 

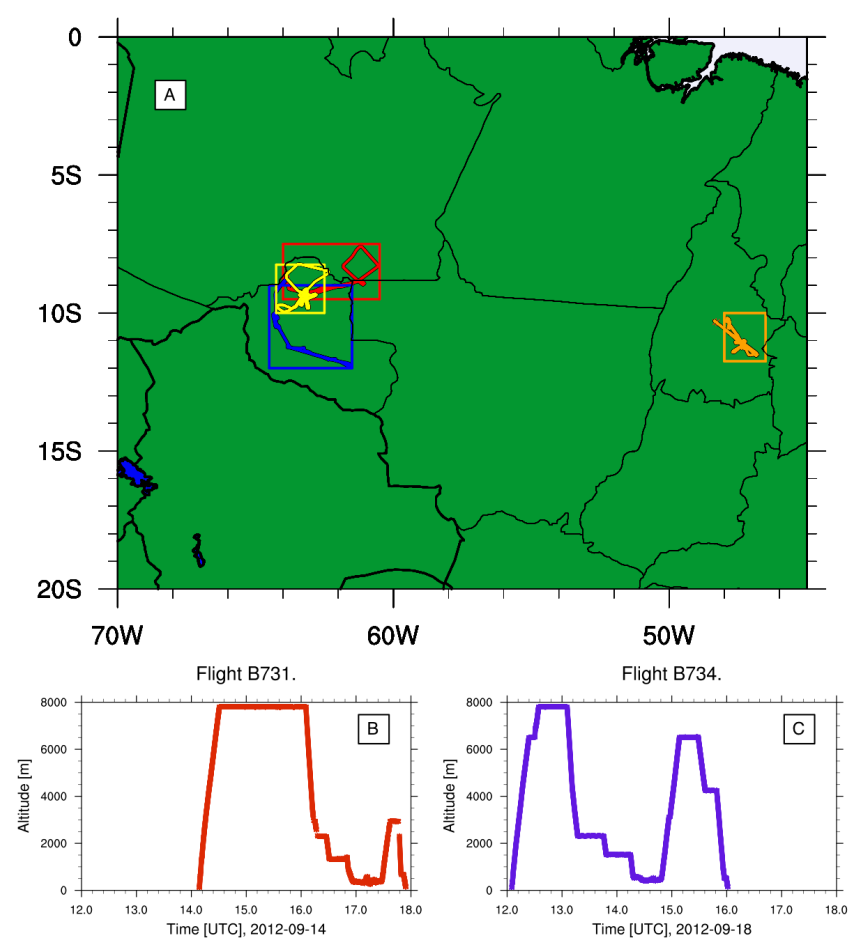

Flight B739.
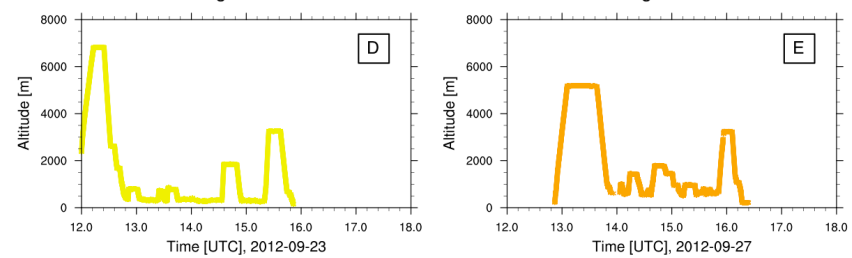

Figure 7. (a) Map of SAMBBA flight trajectories. Red: B731, 14 September 2012. Blue: B734, 18 September 2012. Yellow: B739, 23 September 2012. Orange: B742, 27 September 2012. Lines show the path taken by flights, boxes show regions in model averaged over when comparing between model and flight data. (b-e), altitude tracks of the four flights used for case studies.

good agreement between aircraft and satellite derived AOD it can be inferred that the magnitude of aerosol loadings are unlikely (see Darbyshire et al., 2015). This elevated peak results from a combination of high plume-risen injected emissions and convective transport.

Flight B742 was carried out in the eastern Tocantins state. This region is dominated by cerrado fires. It is clear that the magnitude of emissions are too low in the region. $\mathrm{CO}$, POM and $b_{\text {scat }}$ are higher in the modified emissions scenario, but still approximately $50 \%$ below measured. However, the shape of the vertical profile is well represented, with flights and both model scenarios showing aerosol and $\mathrm{CO}$ well mixed within the boundary layer, and little above it. The lower carbon density of the cerrado biome to tropical forests results in less intense fires, with the injection height rarely much higher than the top of the boundary layer.
Overall, flight B734 shows the closest correspondence between the measurements and model data of the case studies. The modified emissions do produce on average a more reasonable injection height to represent flaming emissions. However, there is still a strong bias towards overestimating the injection height, particularly over tropical forest biomes. This is most apparent in POM. Modelled CO may be similar to flights even where POM diverges. $b_{\text {scat }}$ decreases exponentially with altitude, meaning the high altitude layers are optically thinner than those in the boundary layer. However, this may still be a significant divergence from reality, given the negligible measured $b_{\text {scat }}$ at these heights.

\subsubsection{Composition, optical properties and size distribution of aerosol}

Box and whisker plots of $\mathrm{BC}, \mathrm{POM}: \mathrm{BC}$ ratio and single scattering albedo $\left(\omega_{0}\right)$ for the straight level runs below $3 \mathrm{~km}$ of the atmosphere are shown in Fig. 9. The SP2 had insufficient coverage during flight $\mathrm{B} 731$ to provide $\mathrm{POM}: \mathrm{BC}$ ratios, hence these are not included here. However, $\omega_{0}$ measurements for this flight are presented in the Supplement. Model data is from the modified emissions scenario, extracted along the flight path by finding the $x-y$ grid point closest to the flight measurement, then linearly interpolating in the vertical and time to the altitude and time of reading. There was little difference in composition between the two scenarios.

The western flights show a higher POM : $\mathrm{BC}$ ratio on average compared to the Eastern flight B742. In both western flights, the modelled POM : $\mathrm{BC}$ ratio is much lower than measured, due to the increased loadings of $\mathrm{BC}$. The modelled POM : $\mathrm{BC}$ ratio is consistently between 9 and 11, slightly higher on B739 and lower in B742. The median measured ratio for B734 is 14.5 and for B739 it is 17.6. B739 is likely higher due to the increased proportion of smouldering fires post precipitation, which tend to have higher $\mathrm{POM}: \mathrm{BC}$ ratio. In the eastern flight B742, the median POM : BC ratio is 9.1, similar to that modelled, although the range is still larger. The lower POM : BC ratio in flight B742 is likely due to the higher proportion of cerrado fires.

The POM: $\mathrm{BC}$ ratio shows a lot more variability in the flight data compared to the model. The variation is likely due to a combination of varying emission factors (EF) due to fuel type, flaming temperature, burning efficiency and other factors (Jolleys et al., 2012); and SOA formation (Jimenez et al., 2009). The model emissions do not vary in composition to the same extent, due to limited measurements driving the Andreae and Merlet (2001) EF, and no SOA formation is represented in the MOSAIC mechanism. Some recent measurements, such as Jolleys et al. (2012), suggest that, unlike urban plumes, there is little net SOA formation during the ageing of BB plumes, supporting the primary OC assumption in heavily BB influenced regions. However, other studies, such as Vakkari et al. (2014), suggest growth by SOA 
Flight B731.
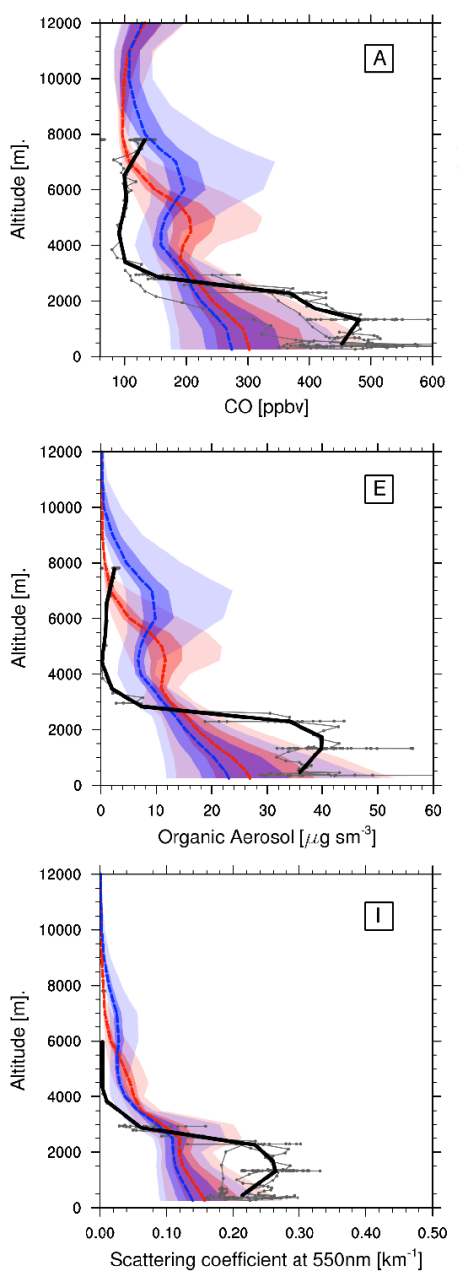

Flight B734.
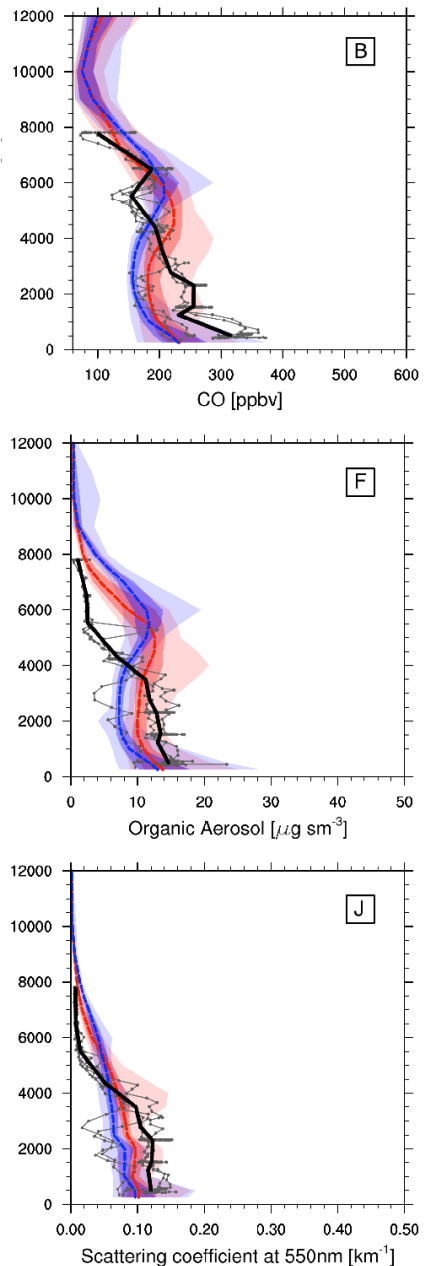

Flight B739.
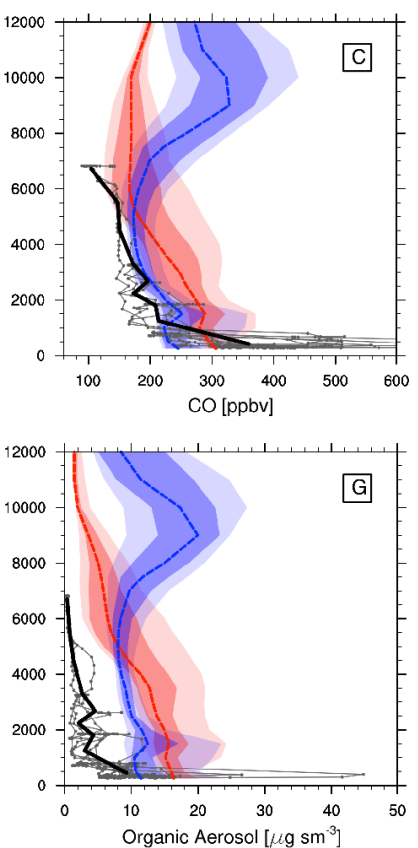

Organic Aerosol $\left[\mathrm{ug} \mathrm{sm}^{-3}\right]$

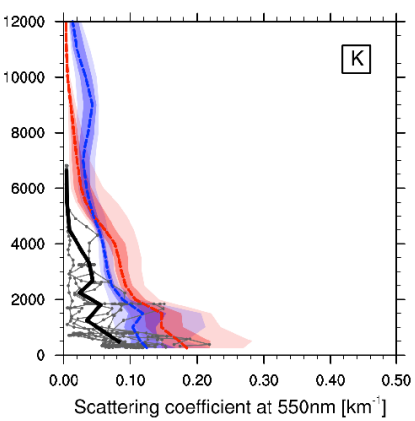

Flight B742.
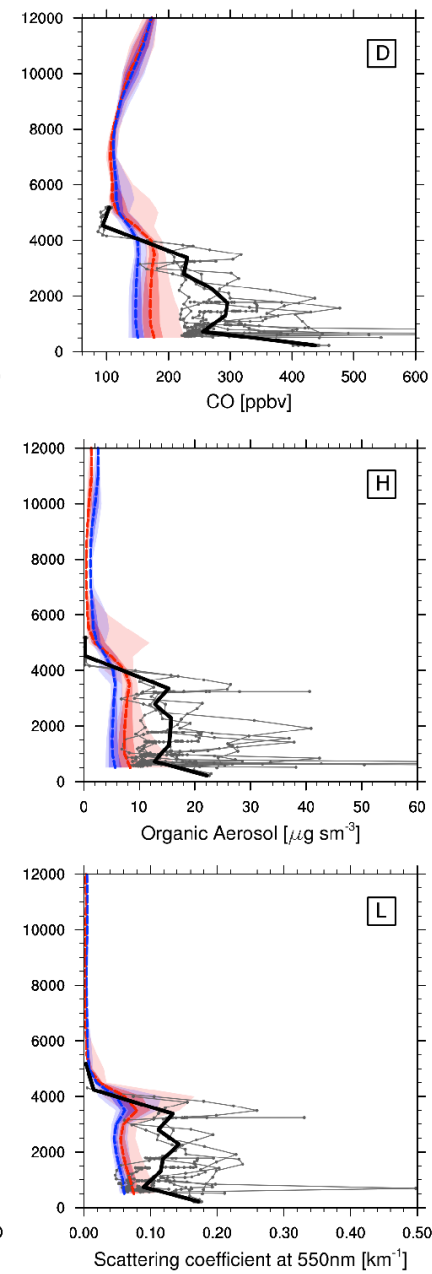

Figure 8. Vertical profiles of CO (ppbv), POM $\left(\mu \mathrm{g} \mathrm{sm}{ }^{-3}\right)$ and $b_{\text {scat }}$ at $550 \mathrm{~nm}\left(\mathrm{~km}^{-1}\right)$. (a, e and i) from flight B731 (14 September 2012); (b, $\mathbf{f}$ and $\mathbf{j}$ ) from flight B734 (18 September); (c, $\mathbf{g}$ and $\mathbf{k}$ ) from flight B739 (23 September); and (d, h and $\mathbf{l}$ ) from flight B742 (27 September). The red dashed lines show the median from the modified emissions scenario, with the strong red shaded region showing the interquartile range and the faded region the fifth to the ninety-fifth percentile range. The blue lines and shaded regions are for the standard 3BEM emissions scenario; a solid black line shows median line of profiles conducted by flights; the fine grey lines show flight measurements averaged over every $3 \mathrm{~min}$.

condensation in the first few hours of plume ageing is a significant factor in determining BBA composition.

Modelled $\omega_{0}$ is largely controlled by the ratio of $\mathrm{BC}$ to other aerosol components. In flights B734 and B739, the flight average is similar to modelled $\omega_{0}$. B739 shows a much greater degree of variability, with an interquartile range (IQR) of 0.81-0.95. However, it should be noted that the PSAP instrument had only partial coverage during this flight, which may be skewing some of the data. While the POM : BC ratio is always lower in the model, $\omega_{0}$ is often lower in the measurements. Given the low modelled POM : BC ratio, the model should be underestimating $\omega_{0}$ by a similar margin; i.e. it is getting $\omega_{0}$ right for the wrong reasons. In contrast, flight B742 has a similar POM : BC ratio between flight and model but significantly lower $\omega_{0}$ (the model is getting it wrong for the right reasons). The implication is that there are properties of the aerosol affecting how it absorbs radiation not being captured in the model. The mixing rule (in this case Maxwell-Garnett) may be under-predicting the absorption amplification of the other aerosol components and/or the organic portion of the aerosol should be slightly absorbing in the visible spectrum ("brown" carbon). In addition, recent WRF-Chem developments have enabled explicit modelling of the mixing state of $\mathrm{BC}$ with other components (Matsui et al., 2013). While more expensive to run, using this method may improve predictions of aerosol absorption.

Figure 10 shows the $\mathrm{CCN}$ concentration, number and volume distributions of aerosol from flights B734 and B742 compared with the modified emission scenario. Data was extracted from the model along the flight path. In both flights, 

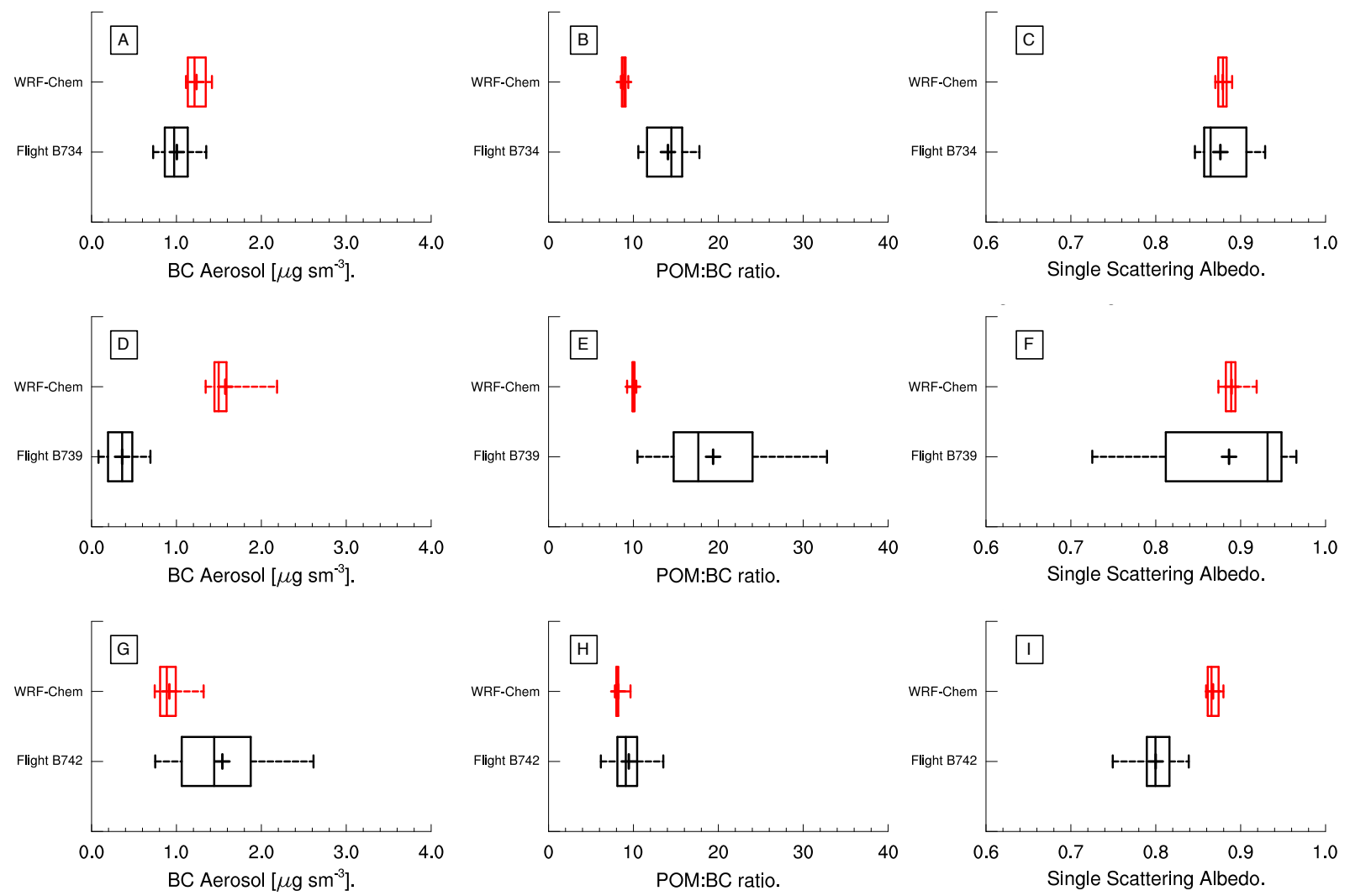

Figure 9. Box-whisker plots of black carbon $\left(\mathrm{BC}, \mu \mathrm{g} \mathrm{sm}{ }^{-3}\right)$, particulate organic matter to black carbon ratio (POM : BC) and single scattering albedo $\left(\omega_{0}\right)$. Box bounds show interquartile range, the end of dashed lines the fifth and ninety-fifth percentiles, and cross indicates the mean. Showing spread of data from flights and extracted along flight path from modified emissions WRF-Chem run. Screened to only show data from straight-level runs below $3.25 \mathrm{~km}$ a.s.l.. Flight data averaged over 3 min periods (approximately the time taken to travel across one $25 \mathrm{~km}$ grid cell). Panels (a, d and $\mathbf{g}$ ) are for flight B734 (18 September); panels (b, e and h) for flight B739 (23 September); and panels (c, f and i) for flight B742 (27 September).

the peak in the size distribution is the same (within error), showing that the studies the modelled distribution is based on are representative of regional BBA. However, the modelled distribution is too wide, with too much aerosol in the larger bins between 1 and $5 \mu \mathrm{m}$ and too little in the accumulation mode. This implies that there is too much emitted coarse mode BBA, there is another source of coarse aerosol (e.g. dust) in the model not observed in the flight, too much coarse aerosol is being transported up to flight height, or the process of larger BBA particles being preferentially removed by precipitation (as Taylor et al., 2014, show with Canadian fires) is not being well captured in the model. However, it should be noted that the GRIMM data has some minor uncertainties attributed to it due to line-losses and refractive index, and so the results presented here should be seen as a lower limit. Further sensitivity work is needed to test which of these factors are more important. The model represents the spread of CCN well in flight B734, with the measured CCN at between 0.135 and $0.154 \%$ supersaturation in between the modelled $\mathrm{CCN}_{0.1}$ and $\mathrm{CCN}_{0.2}$ values. The model also underestimates CCN concentrations over flight B742, in line with the under-prediction of aerosol loadings over the eastern regions.

\section{Conclusions}

We have modified the online coupled regional model WRFChem to use 3BEM emissions and plume-rise parameterisation with the MOSAIC sectional aerosol and CBM-Z gas phase chemistry mechanisms. The default values of both active the fire size and burned area given in PREP-CHEM-SRC are 22.8 ha (Longo et al., 2010). Using these values it was found that the injection height was often biased high. Given the downward trend in fire sizes in Brazil from 2000, emissions suitable for the 2012 Brazilian biomass burning season were developed using estimates based on FRP measurements over the region, with different values for different biomes. In the modified inventory, burned area and active fire size are treated independently, with burned area used to calculate the emitted mass and active fire size to calculate the injection height of the plume-rise parameterisation. Results from 

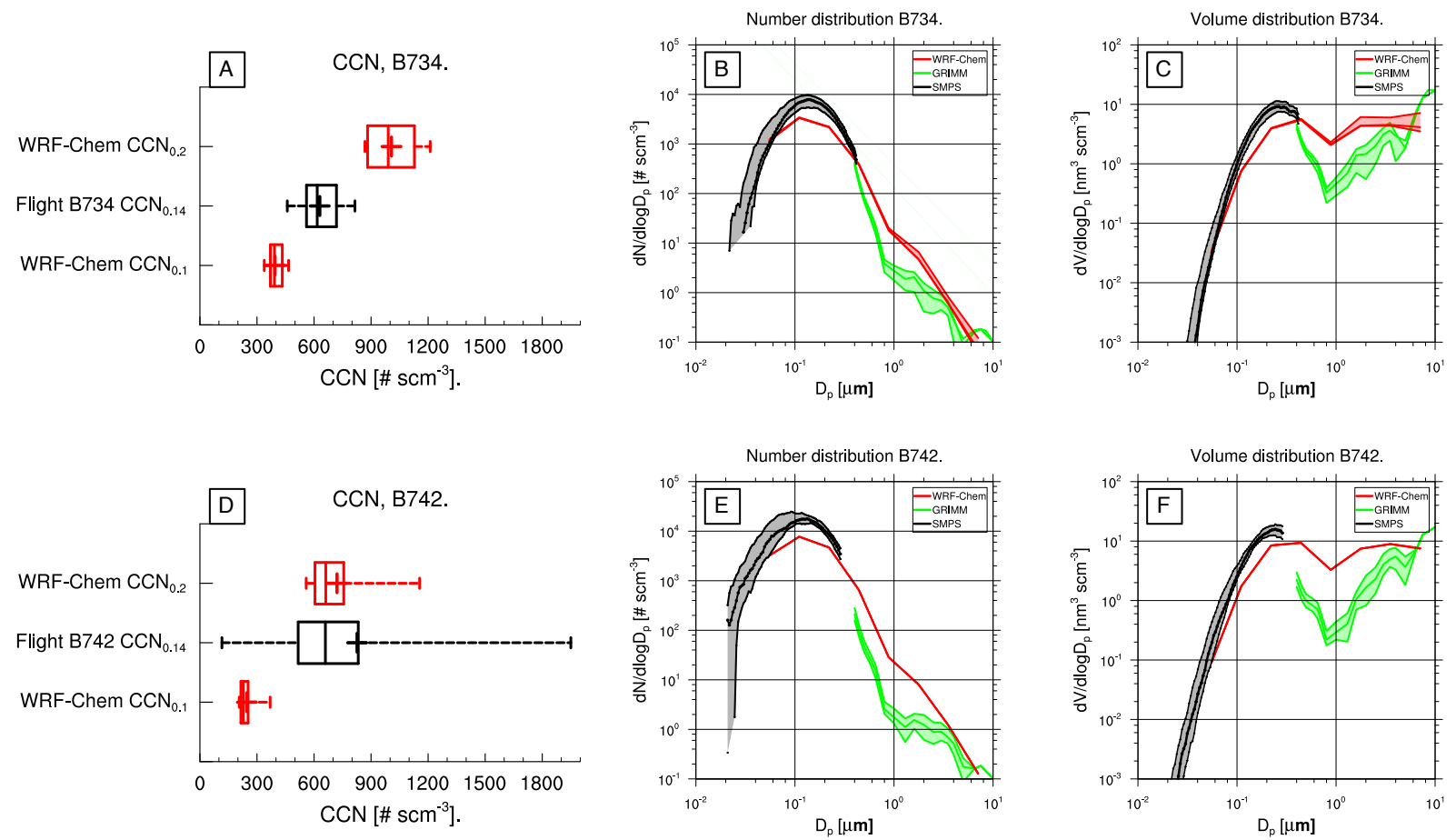

Figure 10. Plots of $\mathrm{CCN}$ concentration $\left(\mathrm{scm}^{-3}\right)$ and size distribution $\mathrm{d} N / \mathrm{dlog}_{10}\left(D_{\mathrm{p}}\right)\left(\mathrm{scm}^{-3}\right)$. Comparing flight data from flights $\mathrm{B} 734$ (a, b and c) and B742 (d, e and f) with model data from modified emissions run. Model data extracted along flight path and interpolated in vertical axis and in time. $\mathrm{CCN}$ plots show $\mathrm{CCN}$ concentration at approximately $0.14 \%$ supersaturation $\left(\mathrm{CCN}_{0.14}\right)$ from measurements, with $\mathrm{CCN}$ concentrations at 0.1 and $0.2 \%$ supersaturation $\left(\mathrm{CCN}_{0.1}, \mathrm{CCN}_{0.2}\right)$ from model. Number and volume size distributions show data from WRF-Chem modified emission scenario across the full 8-bin MOSAIC size range (red), the SMPS instrument below $0.3 \mu \mathrm{m}$ (black) and the GRIMM instrument above $0.3 \mu \mathrm{m}$ (green). The central lines show median and the shaded regions show interquartile range.

model simulations have been compared against in situ measurements from the SAMBBA flight campaign.

In many modelling studies, an enhancement factor $\left(f_{x}\right)$ is required to scale fire emissions to produce reasonable AODs (e.g. Wu et al., 2011a; Kaiser et al., 2012; Tosca et al., 2013). The need for $f_{x}$ highlights the many uncertainties in calculating biomass burning emissions (Ichoku et al., 2012). In this study, we found that when we modified the estimated burned area for 2012 values, the total emitted mass was significantly smaller. We therefore increased $f_{x}$ from 1.3 to 5 to produce reasonable AODs within the model. The implication is that using the standard $3 \mathrm{BEM}$ emission product the modelled AOD was reasonable, but only because the burned area was larger than the 2012 season average. Using our best estimate of burned area required a scaling of emissions to compensate.

In the western regions over the first half of the campaign, modelled AODs compared well to satellite measurements. However, AODs were consistently overestimated in the second part, when there was more precipitation. Over eastern cerrado regions, the model underestimated AOD over the whole campaign. There are several factors that may explain these observations. Firstly, the average burned areas used in the study did not vary over the course of the cam- paign. Secondly, small fires are often not detected. Randerson et al. (2012) estimate that some $35 \%$ of fire emissions are missed globally due to lack of detection of small fires, with this factor being larger in some regions. Observations on the SAMBBA flights were that in some regions there were more than one fire per $\mathrm{km}^{2}$, particularly in the eastern cerrado burning states, which would be identified as a single fire. Finally, the Yevich and Logan (2003) inventory was used to account for small biofuel and agricultural burnings. However, this inventory provides annual averages for emissions, which are known to show large seasonal variability (Duncan, 2003). Adding a function to control the seasonal variation of these emissions and increase their contribution in the dry season should provide better estimates, particularly over agricultural areas such the eastern cerrado states.

Over the western flights, which were dominated by tropical forest fires (and pasture burnings), there was too much emitted mass at high altitude in both model scenarios. With fire size significantly smaller in the modified emission scenario, the injection height was typically $2-3 \mathrm{~km}$ lower, but still approximately $2 \mathrm{~km}$ above the boundary layer. The distribution of fire size is positively skewed, with the majority of fires being small ( $\ll 5 \mathrm{ha}$ ) and only a few large fires (some 
50 ha or larger). A probabilistic representation of this distribution may be needed.

The vertical stability in the atmospheric column from the model was compared with drop-sonde measurements from the flights. The coarse structure was well captured but much of the fine detail was not. The model failed to reproduce the temperature and dewpoint inversions at the top of the boundary layer, likely due to vertical resolution issues and limitations of the PBL parameterisation. The stability profile from the parent model is used to define the column of the plume-rise parameterisation. Without a clearly defined stable layer, it is perhaps unsurprising that it often penetrates the PBL. Forcing a small temperature inversion at the PBL top may improve the plume-rise parameterisation's accuracy, but day to day and geographical variability makes such an intervention impossible without comparison of the hindcast with measured data.

The vertical distribution of carbon monoxide (CO), particulate organic matter $(\mathrm{POM})$ and scattering coefficient $\left(b_{\text {scat }}\right)$ were compared between model runs and flight measurements. The modelled $\mathrm{CO}$ vertical profile was reasonably well represented, as seen in previous studies (Freitas et al., 2007, 2009; Longo et al., 2010). However, there were regions of elevated aerosol layers in the model not observed in flight measurements. Aerosol has many more loss processes than CO, particularly through wash-out. Andreae et al. (2001) show convective transport of tropical BBA is important for forming aerosol layers at high altitude. However, only around 5-20\% of accumulation mode aerosol is retained during transport; the rest is washed out. The plume-rise parameterisation transports $100 \%$ of flaming emissions when convection is triggered. Accounting for the aerosol loss processes attributed to convection during plume-rise may be needed to better represent the aerosol profile.

The model failed to represent the same variation in aerosol composition and $\omega_{0}$ observed in the flights. This composition in the model is driven by the Andreae and Merlet (2001) emission factors (EF). Akagi et al. (2011) have reviewed many more recent studies to provide newer estimates. The $\mathrm{OC}: \mathrm{BC}$ ratio for savannah has remained the same at 7.08. However, the estimated tropical forest EF increased from 7.88 to 9.05 , approximately $15 \%$ higher. Using these updated EF would bring the model closer to measured POM : $\mathrm{BC}$ ratios in the western flights. Work is underway to update the PREP-CHEM-SRC to the EF of Akagi et al. (2011). Representing flight B739 will still be a challenge however, given the impact of precipitation on fire conditions. This may be accounted for using dynamic EF varying with, for example, soil moisture. More detailed measurements would need to be collected and reviewed to develop an emissions inventory with this flexibility. It should also be noted that comparisons are between modelled primary organic matter and measured total organic matter (including SOA mass). Work is being conducted to run WRF-Chem with a volatility basis set (VBS; Donahue et al., 2011; Shrivastava et al., 2011) over the SAMBBA period to simulate SOA formation and enable more in-depth aerosol compositional comparisons with flight cToF-AMS data.

Modelled $\omega_{0}$ was often too high when the POM : BC ratio was approximately correct, and close to measured when POM : BC ratio was too low. This indicates failure of the model to accurately predict the aerosol optical properties from the composition. The model may be underestimating the enhancement factor of $\mathrm{BC}$ and a better mixing rule is needed (such as shell-core), or explicit modelling of the BC mixing state (Matsui et al., 2013). Some SW absorption due to the "brown carbon" components of organic aerosol is also likely needed (Lack et al., 2012, 2013; Saleh et al., 2014). The discrepancies highlight the need to capture the full mixing state, including both SOA and POA, as well as condensable inorganic vapours, to accurately predict aerosol optical properties.

The model represented size distribution peak location well in flights B734 and B742. CCN concentrations correspond well over the western flight $\mathrm{B} 734$, with $\mathrm{CCN}_{0.2}$ between 900 and $1100 \mathrm{scm}^{-3}$ within the boundary layer. Over the eastern flight, the model under-predicted CCN concentration. However, the low CCN concentrations are in line with the low aerosol loadings over this flight and period. 


\section{Appendix A: MACC-II boundary conditions}

Only a subset of chemical species thought to be significant in long-range transport and chemistry are included in the MACC-II product: $\mathrm{CO} ; \mathrm{O}_{3} ; \mathrm{OH} ; \mathrm{SO}_{2} ; \mathrm{NO}_{2} ; \mathrm{HNO}_{3} ; \mathrm{CH}_{4}$; $\mathrm{C}_{2} \mathrm{H}_{6}$; isoprene; peroxyacetyl nitrate (PAN); and formaldehyde (HCHO). The aerosol module used in MACC-II is described by Morcrette et al. (2009). Five species of aerosol are carried: natural sea salt (SU); dust (DU); and three anthropogenic aerosols (POM, BC and SULF). SULF, POM and $\mathrm{BC}$ are each treated as bulk aerosol, with $\mathrm{BC}$ and $\mathrm{POM}$ treated as two components - hydrophobic and hygrophilic. SS and DU are each represented by bins with boundaries at $0.03,0.5,5$ and $20 \mu \mathrm{m}$ diameter for SS and $0.03,0.55,0.9$ and $20 \mu \mathrm{m}$ for DU (Morcrette et al., 2009).

The model uses log-normal distributions with parameters of mean diameter $\left(D_{\mathrm{p}}\right)$ and geometric standard deviation $(\sigma)$ as defined below (J.-J. Morcrette, personal communication, 2013):

- SS: two log-normal distributions; the first with $D_{\mathrm{p}, 1}=0.389 \mu \mathrm{m}, \sigma_{\mathrm{p}, 1}=1.9, \quad N_{\mathrm{tot}, 1}=70$, the second with $D_{\mathrm{p}, 2}=3.984 \mu \mathrm{m}, \sigma_{\mathrm{p}, 2}=2.0, N_{\mathrm{tot}, 2}=3$.

- DU: a single log-normal distribution, $D_{\mathrm{p}}=0.58 \mu \mathrm{m}$, $\sigma_{\mathrm{p}}=2.0$.

- The bulk aerosol BC, POM and $\mathrm{SO}_{4}^{2-}$ is assumed to be in an accumulation mode with single log-normal distribution, $D_{\mathrm{p}}=0.071 \mu \mathrm{m}, \sigma_{\mathrm{p}}=2.0$.
The fraction of each MACC-II bin to be partitioned into each MOSAIC bin is given by the fraction of each distribution that falls between each MOSAIC bin boundary. As the upper limit of MOSAIC aerosol is $10 \mu \mathrm{m}$, all aerosol mass from the distributions above $10 \mu \mathrm{m}$ is discarded. See Table 3 for full apportionment to each MOSAIC size bin.

The SULF carried in MACC-II is assumed to be ammonium sulfate $\left(\left(\mathrm{NH}_{4}\right)_{2} \mathrm{SO}_{4}\right)$ when mapped to the WRF-Chem MOSAIC species, in order for the aerosol to have neutral acidity. Likewise, $\mathrm{SS}$ is assumed to be $\mathrm{NaCl}$ and is split between the $\mathrm{Na}^{+}$and $\mathrm{Cl}^{-}$ions. The MACC-II boundary conditions were interpolated to the model grid using a modified version of the mozbc script (www.acd.ucar.edu/wrf-chem). 


\section{The Supplement related to this article is available online at doi:10.5194/gmd-8-549-2015-supplement.}

Acknowledgements. This work was funded by the Nature Environment Research Council (NERC) as part of the SAMBBA project under grant NE/J010073/1. S. Archer-Nicholls was supported by a Nature Environment Research Council (NERC) quota studentship, with partial support from NERC grant NE/J009202/1. S. Freitas acknowledges partial support of the work by CNPq (306340/2011-9). J. Kaiser was funded by the EU FP7 project MACC-II (grant agreement 283576) and SAMBBA NERC grant NE/J010073/1. The Facility for Airborne Atmospheric Measurement (FAAM) BAe-146 Atmospheric Research Aircraft is jointly funded by the UK Met Office and NERC and operated by DirectFlight Ltd. We thank the National Institute for Space Research (INPE), University of São Paulo, the Brazilian Ministry of Science and Technology, and all the instrument operators on board the flights for making the SAMBBA measurement campaign possible.

Meteorological and MACC-II boundary conditions were provided by the European Centre for Medium-range Weather Forecasts (ECMWF). We thank J.-J. Morcrette for advice and help acquiring MACC-II data and providing information needed to generate sensible size distributions for MOSAIC. S. Walters from UCAR for editing the mozbc script for use with MACC-II boundary conditions. We thank all the PIs, missions scientists and staff operating the AErosol RObotic NETwork (AERONET) sites and at NASA who provided data for this study. The TMPA data were provided by the NASA/Goddard Space Flight Centre's Mesoscale Atmospheric Processes Laboratory and PPS, which develop and compute the TMPA as a contribution to TRMM. MODIS AOD data was accessed via http://disc.sci.gsfc.nasa.gov/giovanni/.

Model runs were carried out on the High End Computing Terascale Resources (HECToR) British national supercomputer. Analysis and figures were generated using NCAR Command Language V. 6.1.2 (doi:10.5065/D6WD3XH5). We thank all the developers of example scripts and WRF-specific functions we used and developed.

Finally, we would like to thank J. Reid and the four other anonymous reviewers for their helpful and positive comments, which helped improve the manuscript considerably.

Edited by: J. Williams

\section{References}

Abdul-razzak, H. and Ghan, S. J.: A parameterization of aerosol activation 3. Sectional representation, J. Geophys. Res., 107, 4026, doi:10.1029/2001JD000483, 2002.

Ackermann, I. J., Hass, H., Memmesheimer, M., Ebel, A., Binkowski, F. S., and Shankar, U.: Modal aerosol dynamics model for Europe: development and first applications, Atmos. Environ., 32, 2981-2999, 1998.

Ackerman, T. P. and Toon, O. B.: Absorption of visible radiation in atmosphere containing mixtures of absorbing and nonabsorbing particles, Appl. Optics, 21, 758, doi:10.1364/AO.21.000758, 1982.
Akagi, S. K., Yokelson, R. J., Wiedinmyer, C., Alvarado, M. J., Reid, J. S., Karl, T., Crounse, J. D., and Wennberg, P. O.: Emission factors for open and domestic biomass burning for use in atmospheric models, Atmos. Chem. Phys., 11, 4039-4072, doi:10.5194/acp-11-4039-2011, 2011.

Andela, N., Kaiser, J. W., Heil, A., van Leeuwen, T. T., Wooster, M. J., van der Werf, G. R., Remy, S., and Schultz, M. G.: Assessment of the Global Fire Assimilation System (GFASv1), Tech. Memo. 702, European Centre for Mediumrange Weather Forecasts (ECMWF), Reading, UK, 2013.

Anderson, T. L. and Ogren, J. A.: Determining aerosol radiative properties using the TSI 3563 integrating nephelometer, Aerosol Sci. Tech., 29, 57-69, doi:10.1080/02786829808965551, 1998.

Anderson, T. L., Covert, D. S., Marshall, S. F., Laucks, M. L., Charlson, R. J., Waggoner, A. P., Ogren, J. A., Caldow, R., Holm, R. L., Quant, F. R., Sem, G. J., Wiedensohler, A., Ahlquist, N. A., and Bates, T. S.: Performance Characteristics of a High-Sensitivity, Three-Wavelength, Total Scatter/Backscatter Nephelometer, J. Atmos. Ocean. Tech., 13, 967-986, doi:10.1175/15200426(1996)013<0967:PCOAHS>2.0.CO;2, 1996.

Andreae, M. O. and Merlet, P.: Emission of trace gases and aerosols from biomass burning, Global Biogeochem. Cy., 15, 955-966, 2001.

Andreae, M. O., Artaxo, P., Fischer, H., Freitas, S. R., Grgoire, J.-M., Hansel, A., Hoor, P., Kormann, R., Krejci, R. Lange, L., Lelieveld, J., Lindinger, W., Longo, K., Peters, W., de Reus, M., Scheeren, B., Silva Dias, M. A. F., Strm, J., van Velthoven, P. F. J., and Williams, J.: Transport of biomass burning smoke to the upper troposphere by deep convection in the equatorial region, Geophys. Res. Lett., 28, 951-954, doi:10.1029/2000GL012391, 2001.

Andreae, M. O., Rosenfeld, D., Artaxo, P., Costa, A. A., Frank, G. P., Longo, K. M., and Silva-Dias, M. A. F.: Smoking rain clouds over the Amazon, Science, 303, 1337-1342, doi:10.1126/science.1092779, 2004.

Arai, E., Shimabukuro, Y. E., Pereira, G., and Vijaykumar, N. L.: A multi-resolution multi-temporal technique for detecting and mapping deforestation in the Brazilian Amazon rainforest, Remote Sens. Environ., 3, 1943-1956, doi:10.3390/rs3091943, 2011.

Artaxo, P., Rizzo, L. V., Brito, J. F., Barbosa, H. M. J., Arana, A., Sena, E. T., Cirino, G. G., Bastos, W., Martin, S. T., and Andreae, M. O.: Atmospheric aerosols in Amazonia and land use change: from natural biogenic to biomass burning conditions, Faraday Discuss., 165, 203, doi:10.1039/c3fd00052d, 2013.

Bahreini, R., Ervens, B., Middlebrook, A. M., Warneke, C., de Gouw, J. A., DeCarlo, P. F., Jimenez, J. L., Brock, C. A., Neuman, J. a., Ryerson, T. B., Stark, H., Atlas, E., Brioude, J., Fried, A., Holloway, J. S., Peischl, J., Richter, D., Walega, J., Weibring, P., Wollny, A. G., and Fehsenfeld, F. C.: Organic aerosol formation in urban and industrial plumes near Houston and Dallas, Texas, J. Geophys. Res., 114, D00F16, doi:10.1029/2008JD011493, 2009.

Baklanov, A., Schlünzen, K., Suppan, P., Baldasano, J., Brunner, D., Aksoyoglu, S., Carmichael, G., Douros, J., Flemming, J., Forkel, R., Galmarini, S., Gauss, M., Grell, G., Hirtl, M., Joffre, S., Jorba, O., Kaas, E., Kaasik, M., Kallos, G., Kong, X., Korsholm, U., Kurganskiy, A., Kushta, J., Lohmann, U., Mahura, A., Manders-Groot, A., Maurizi, A., Moussiopoulos, N., Rao, S. T., 
Savage, N., Seigneur, C., Sokhi, R. S., Solazzo, E., Solomos, S., Sørensen, B., Tsegas, G., Vignati, E., Vogel, B., and Zhang, Y.: Online coupled regional meteorology chemistry models in $\mathrm{Eu}-$ rope: current status and prospects, Atmos. Chem. Phys., 14, 317398, doi:10.5194/acp-14-317-2014, 2014.

Ban-Weiss, G. A., Cao, L., Bala, G., and Caldeira, K.: Dependence of climate forcing and response on the altitude of black carbon aerosols, Clim. Dynam., 38, 897-911, doi:10.1007/s00382-0111052-y, 2011.

Barnard, J. C., Fast, J. D., Paredes-Miranda, G., Arnott, W. P., and Laskin, A.: Technical Note: Evaluation of the WRF-Chem "Aerosol Chemical to Aerosol Optical Properties" Module using data from the MILAGRO campaign, Atmos. Chem. Phys., 10, 7325-7340, doi:10.5194/acp-10-7325-2010, 2010.

Baumgardner, D., Kok, G., and Raga, G.: Warming of the Arctic lower stratosphere by light absorbing particles, Geophys. Res. Lett., 31, L06117, doi:10.1029/2003GL018883, 2004.

Beck, V., Gerbig, C., Koch, T., Bela, M. M., Longo, K. M., Freitas, S. R., Kaplan, J. O., Prigent, C., Bergamaschi, P., and Heimann, M.: WRF-Chem simulations in the Amazon region during wet and dry season transitions: evaluation of methane models and wetland inundation maps, Atmos. Chem. Phys., 13, 7961-7982, doi:10.5194/acp-13-7961-2013, 2013.

Bela, M. M., Longo, K. M., Freitas, S. R., Moreira, D. S., Beck, V., Wofsy, S. C., Gerbig, C., Wiedemann, K., Andreae, M. O. and Artaxo, P.: Ozone production and transport over the Amazon Basin during the dry-to-wet and wet-to-dry transition seasons, Atmos. Chem. Phys., 15, 757-782, doi:10.5194/acp-15757-2015, 2015.

Benedetti, A., Morcrette, J.-J., Boucher, O., Dethof, A., Engelen, R. J., Fisher, M., Flentje, H., Huneeus, N., Jones, L., Kaiser, J. W., Kinne, S., Mangold, A., Razinger, M., Simmons, A. J., and Suttie, M.: Aerosol analysis and forecast in the European Centre for Medium-Range Weather Forecasts Integrated Forecast System: 2. Data assimilation, J. Geophys. Res., 114, D13205, doi:10.1029/2008JD011115, 2009.

Bond, T. C. and Bergstrom, R. W.: Light absorption by carbonaceous particles: an investigative review, Aerosol Sci. Technol., 40, 27-67, doi:10.1080/02786820500421521, 2006.

Bond, T. C., Anderson, T. L., and Campbell, D.: Calibration and intercomparison of filter-based measurements of visible light absorption by aerosols, Aerosol Sci. Technol., 30, 582-600, doi:10.1080/027868299304435, 1999.

Bond, T. C., Habib, G., and Bergstrom, R. W.: Limitations in the enhancement of visible light absorption due to mixing state, J. Geophys. Res., 111, D20211, doi:10.1029/2006JD007315, 2006.

Bond, T. C., Doherty, S. J., Fahey, D. W., Forster, P. M., Berntsen, T., Deangelo, B. J., Flanner, M. G., Ghan, S., Koch, D., Kinne, S., Kondo, Y., Quinn, P. K., Sarofim, M. C., Schultz, M. G., Schulz, M., Zhang, H., Zhang, S., Bellouin, N., Guttikunda, S. K., Hopke, P. K., Jacobson, M. Z., Klimont, Z., Lohmann, U., Schwarz, J. P., Shindell, D., Storelvmo, T., Warren, S. G., and Zender, C. S.: Bounding the role of black carbon in the climate system: a scientific assessment, J. Geophys. Res.Atmos., 11, 1-163, 2013.

Boucher, O., Randall, D., Artaxo, P., Bretherton, C., Feingold, G., Forster, P., Kerminen, V.-M., Kondo, Y., Liao, H., Lohmann, U., Rasch, P., Satheesh, S. K., Sherwood, S., Stevens, B., and Zhang, X. Y.: Clouds and aerosols, in: Climate Change 2013: the Physical Science Basis. Contribution of Working Group I to the Fifth Assessment Report of the Intergovernmental Panel on Climate Change, edited by: Stocker, T. F., Qin, D., Plattner, G.K., Tignor, M., Allen, S. K., Boschung, J., Nauels, A., Xia, Y., Bex, V., and Midgley, P. M., Cambridge University Press, Cambridge, UK and New York, NY, USA, 2013.

Brito, J., Rizzo, L. V., Morgan, W. T., Coe, H., Johnson, B., Haywood, J., Longo, K., Freitas, S., Andreae, M. O., and Artaxo, P.: Ground-based aerosol characterization during the South American Biomass Burning Analysis (SAMBBA) field experiment, Atmos. Chem. Phys., 14, 12069-12083, doi:10.5194/acp-1412069-2014, 2014.

Canagaratna, M. R., Jayne, J. T., Jimenez, J. L., Allan, J. D., Alfarra, M. R., Zhang, Q., Onasch, T. B., Drewnick, F., Coe, H., Middlebrook, A., Delia, A., Williams, L. R., Trimborn, A. M., Northway, M. J., Decarlo, P. F., Kolb, C. E., Davidovits, P., and Worsnop, D. R.: Chemical and microphysical characterization of ambient aerosols with the aerodyne aerosol mass spectrometer, Mass Spectrom. Rev., 26, 185-222, doi:10.1002/mas.20115, 2007.

Chapman, E. G., Gustafson Jr., W. I., Easter, R. C., Barnard, J. C., Ghan, S. J., Pekour, M. S., and Fast, J. D.: Coupling aerosolcloud-radiative processes in the WRF-Chem model: Investigating the radiative impact of elevated point sources, Atmos. Chem. Phys., 9, 945-964, doi:10.5194/acp-9-945-2009, 2009.

Chin, M., Rood, R. B., Lin, S., Müller, J.-F., and Thompson, A. M.: Atmospheric sulfur cycle simulated in the global model GOCART - Model description and global properties, J. Geophys. Res., 105, 24671-24687, 2000.

Clyne, J., Mininni, P., Norton, A., and Rast, M.: Interactive desktop analysis of high resolution simulations: application to turbulent plume dynamics and current sheet formation, New J. Phys., 301, 9, doi:10.1088/1367-2630/9/8/301, 2007.

Colarco, P. R., Schoeberl, M. R., Doddridge, B. G., Marufu, L. T., Torres, O., and Welton, E. J.: Transport of smoke from Canadian forest fires to the surface near Washington, D.C.: Injection height, entrainment, and optical properties, J. Geophys. Res., 109, D06203, doi:10.1029/2003JD004248, 2004.

Damian, V., Sandu, A., Damian, M., Potra, F., and Carmichael, G. R.: The Kinetic PreProcessor KPP - a software environment for solving chemical kinetics, Comput. Chem. Eng., 26, 1567-1579, 2002.

de Andrade Filho, V. S., Artaxo, P., Hacon, S., Nascimento do Carmo, C., and Cirino I, G.: Aerosols from biomass burning and respiratory diseases in children, Manaus, Northern Brazil, Rev. Saude Publ., 47, 239-247, doi:10.1590/S00348910.2013047004011, 2013.

Dentener, F., Kinne, S., Bond, T., Boucher, O., Cofala, J., Generoso, S., Ginoux, P., Gong, S., Hoelzemann, J. J., Ito, A., Marelli, L., Penner, J. E., Putaud, J.-P., Textor, C., Schulz, M., van der Werf, G. R., and Wilson, J.: Emissions of primary aerosol and precursor gases in the years 2000 and 1750 prescribed data-sets for AeroCom, Atmos. Chem. Phys., 6, 43214344, doi:10.5194/acp-6-4321-2006, 2006.

Donahue, N. M., Epstein, S. A., Pandis, S. N., and Robinson, A. L.: A two-dimensional volatility basis set: 1. organic-aerosol mixing thermodynamics, Atmos. Chem. Phys., 11, 3303-3318, doi:10.5194/acp-11-3303-2011, 2011. 
Dozier, J.: A method for satellite identification of surface temperature fields of subpixel resolution, Remote Sens. Environ., 11, 221-229, 1981.

Drewnick, F., Hings, S. S., DeCarlo, P., Jayne, J. T., Gonin, M., Fuhrer, K., Weimer, S., Jimenez, J. L., Demerjian, K. L., Borrmann, S., and Worsnop, D. R.: A New Time-of-Flight Aerosol Mass Spectrometer (TOF-AMS) instrument description and first field deployment, Aerosol Sci. Technol., 39, 637-658, doi:10.1080/02786820500182040, 2005.

Drewnick, F., Hings, S. S., Alfarra, M. R., Prevot, A. S. H., and Borrmann, S.: Aerosol quantification with the Aerodyne Aerosol Mass Spectrometer: detection limits and ionizer background effects, Atmos. Meas. Tech., 2, 33-46, doi:10.5194/amt-2-332009, 2009.

Duncan, B. N.: Interannual and seasonal variability of biomass burning emissions constrained by satellite observations, J. Geophys. Res., 108, 4100, doi:10.1029/2002JD002378, 2003.

Ek, M. B., Mitchell, K. E., Lin, Y., Rogers, E., Grunmann, P., Koren, V., Gayno, G., and Tarpley, J. D.: Implementation of Noah land surface model advances in the National Centers for Environmental Prediction operational mesoscale Eta model, J. Geophys. Res., 108, 8851, doi:10.1029/2002JD003296, 2003.

Emmons, L. K., Walters, S., Hess, P. G., Lamarque, J.-F., Pfister, G. G., Fillmore, D., Granier, C., Guenther, A., Kinnison, D., Laepple, T., Orlando, J., Tie, X., Tyndall, G., Wiedinmyer, C., Baughcum, S. L., and Kloster, S.: Description and evaluation of the Model for Ozone and Related chemical Tracers, version 4 (MOZART-4), Geosci. Model Dev., 3, 43-67, doi:10.5194/gmd3-43-2010, 2010.

Fast, J. D., Gustafson, W. I., Easter, R. C., Zaveri, R. A., Barnard, J. C., Chapman, E. G., Grell, G. A., and Peckham, S. E.: Evolution of ozone, particulates, and aerosol direct radiative forcing in the vicinity of Houston using a fully coupled meteorology-chemistry-aerosol model, J. Geophys. Res., 111, 129, doi:10.1029/2005JD006721, 2006.

Fisch, G., Tota, J., Machado, L. A. T., Silva Dias, M. A. F., da F. Lyra, R. F., Nobre, C. A., Dolman, A. J., and Gash, J. H. C.: The convective boundary layer over pasture and forest in Amazonia, Theor. Appl. Climatol., 78, 47-59, doi:10.1007/s00704004-0043-x, 2004.

Flemming, J., Peuch, V.-H., Engelen, R., and Kaiser, J.: A European global-to-regional that combines modeling: a novel forecasting system for atmospheric composition operates daily to forecast global air pollution, EM: Air and Waste Management Association's Magazine for Environmental Managers, 6-10, 2013.

Freitas, S. R., Longo, K. M., Chatfield, R., Latham, D., Silva Dias, M. A. F., Andreae, M. O., Prins, E., Santos, J. C., Gielow, R., and Carvalho Jr., J. A.: Including the sub-grid scale plume rise of vegetation fires in low resolution atmospheric transport models, Atmos. Chem. Phys., 7, 3385-3398, doi:10.5194/acp-7-3385-2007, 2007.

Freitas, S. R., Longo, K. M., Silva Dias, M. A. F., Chatfield, R., Silva Dias, P., Artaxo, P., Andreae, M. O., Grell, G., Rodrigues, L. F., Fazenda, A., and Panetta, J.: The Coupled Aerosol and Tracer Transport model to the Brazilian developments on the Regional Atmospheric Modeling System (CATT-BRAMS) Part 1: Model description and evaluation, Atmos. Chem. Phys., 9, 2843-2861, doi:10.5194/acp-9-2843-2009, 2009.
Freitas, S. R., Longo, K. M., Trentmann, J., and Latham, D.: Technical Note: Sensitivity of 1-D smoke plume rise models to the inclusion of environmental wind drag, Atmos. Chem. Phys., 10, 585-594, doi:10.5194/acp-10-585-2010, 2010.

Freitas, S. R., Longo, K. M., Alonso, M. F., Pirre, M., Marecal, V., Grell, G., Stockler, R., Mello, R. F., and Sánchez Gácita, M.: PREP-CHEM-SRC - 1.0: a preprocessor of trace gas and aerosol emission fields for regional and global atmospheric chemistry models, Geosci. Model Dev., 4, 419-433, doi:10.5194/gmd-4419-2011, 2011.

Giglio, L.: Characterization of the tropical diurnal fire cycle using VIRS and MODIS observations, Remote Sens. Environ., 108, 407-421, doi:10.1016/j.rse.2006.11.018, 2007.

Giglio, L. and Justice, C. O.: Effect of wavelength selection on characterization of fire size and temperature, Int. J. Remote Sens., 24, 3515-3520, 2003

Giglio, L. and Kendall, J. D.: Application of the Dozier retrieval to wildfire characterization - a sensitivity analysis, Remote Sens. Environ., 77, 34-49, 2001.

Giglio, L. and Schroeder, W.: A global feasibility assessment of the bi-spectral fire temperature and area retrieval using MODIS data, Remote Sens. Environ., 152, 166-173, doi:10.1016/j.rse.2014.06.010, 2014.

Giglio, L., Descloitres, J., Justice, C. O., and Kaufman, Y. J.: An enhanced contextual fire detection algorithm for MODIS, Remote Sens. Environ., 87, 273-282, doi:10.1016/S00344257(03)00184-6, 2003.

Grell, G. and Baklanov, A.: Integrated modeling for forecasting weather and air quality: a call for fully coupled approaches, Atmos. Environ., 45, 6845-6851, doi:10.1016/j.atmosenv.2011.01.017, 2011.

Grell, G. A. and Devenyi, D.: A generalized approach to parameterizing convection combining ensemble and data assimilation techniques, Geophys. Res. Lett., 29, 10-13, doi:10.1029/2002GL015311, 2002.

Grell, G. A., Peckham, S. E., Schmitz, R., McKeen, S. A., Frost, G., Skamarock, W. C., and Eder, B.: Fully coupled "online" chemistry within the WRF model, Atmos. Environ., 39, 6957-6975, doi:10.1016/j.atmosenv.2005.04.027, 2005.

Grell, G., Freitas, S. R., Stuefer, M., and Fast, J.: Inclusion of biomass burning in WRF-Chem: impact of wildfires on weather forecasts, Atmos. Chem. Phys., 11, 5289-5303, doi:10.5194/acp11-5289-2011, 2011.

Guenther, A., Karl, T., Harley, P., Wiedinmyer, C., Palmer, P. I., and Geron, C.: Estimates of global terrestrial isoprene emissions using MEGAN (Model of Emissions of Gases and Aerosols from Nature), Atmos. Chem. Phys., 6, 3181-3210, doi:10.5194/acp-63181-2006, 2006.

Haywood, J. and Boucher, O.: Estimates of the direct and indirect radiative forcing due to tropospheric aerosols: a review, Rev. Geophys., 38, 513, doi:10.1029/1999RG000078, 2000.

Heim, M., Mullins, B. J., Umhauer, H., and Kasper, G.: Performance evaluation of three optical particle counters with an efficient multimodal calibration method, J. Aerosol Sci., 39, 10191031, doi:10.1016/j.jaerosci.2008.07.006, 2008.

Holben, B. N., Eck, T. F., Slutsker, I., Tanre, D., Buis, J. P., Setzer, A., Vermote, E., Reagan, J. A., Kaufman, Y. J., Nakajima, T., Lavenu, F., Jankowiak, I., and Smirnov, A.: AERONET - a fed- 
erated instrument network and data archive for aerosol characterization, Remote Sens. Environ., 66, 1-16, 1998.

Holben, N., Tanré, D., Smirnov, A., Eck, T. F., Slutsker, I., Newcomb, W. W., Schafer, J. S., Chatenet, B., Lavenu, F., Kaufman, J., Vande Castle, J., Setzer, A., Markham, B., Clark, D., Halthore, R., Karneli, A., Neill, N. T. O., Pietras, C., Pinker, T., Voss, K., and Zibordi, G.: An emerging ground-based aerosol climatology: aerosol optical depth from AERONET, J. Geophys. Res., 106, 12067-12097, 2001.

Hollingsworth, A., Engelen, R. J., Benedetti, A., Dethof, A., Flemming, J., Kaiser, J. W., Morcrette, J.-J., Simmons, A. J., Textor, C., Boucher, O., Chevallier, F., Rayner, P., Elbern, H., Eskes, H., Granier, C., Peuch, V.-H., Rouil, L., and Schultz, M. G.: Toward a monitoring and forecasting system for atmospheric composition: the GEMS project, Bull. Am. Meteorol. Soc., 89, 1147-1164, doi:10.1175/2008BAMS2355.1, 2008.

Hong, S.-Y., Noh, Y., and Dudhia, J.: Ew vertical diffusion package with an explicit treatment of entrainment processes, Mon. Weather Rev., 134, 2318-2341, doi:10.1175/MWR3199.1, 2006.

Huneeus, N., Chevallier, F., and Boucher, O.: Estimating aerosol emissions by assimilating observed aerosol optical depth in a global aerosol model, Atmos. Chem. Phys., 12, 4585-4606, doi:10.5194/acp-12-4585-2012, 2012.

Huffman, G. J., Adler, R. F., Morrissey, M. M., Bolvin, D. T., Curtis, S., Joyce, R., McGavock, B., Susskind, J.: Global precipitation at one-degree daily resolution from multisatellite observations, J. Hydrometeorol., 2, 36-50, doi:10.1175/15257541(2001)002<0036:GPAODD>2.0.CO;2, 2001.

Huffman, G. J., Stocker, E. F., Bolvin, D. T., Nelkin, E. J., and Adler, R. F.: TRMM Version 7 3B42 and 3B43 Data Sets. NASA/GSFC, Greenbelt, MD, available at: http://mirador.gsfc.nasa.gov/cgi-bin/mirador/presentNavigation. $\mathrm{pl}$ ?project=TRMM\&tree=project (last access: 16 September 2014), last updated 2013.

Ichoku, C. and Ellison, L.: Global top-down smoke-aerosol emissions estimation using satellite fire radiative power measurements, Atmos. Chem. Phys., 14, 6643-6667, doi:10.5194/acp14-6643-2014, 2014.

Ichoku, C., Kahn, R., and Chin, M.: Satellite contributions to the quantitative characterization of biomass burning for climate modeling, Atmos. Res., 111, 1-28, doi:10.1016/j.atmosres.2012.03.007, 2012.

Ignotti, E., Valente, J. G., Longo, K. M., Freitas, S. R., Hacon, S., and Artaxo, P.: Impact on human health of particulate matter emitted from burnings in the Brazilian Amazon region, Rev. Saude Publ., 44, 121-130, 2010.

Inness, A., Baier, F., Benedetti, A., Bouarar, I., Chabrillat, S., Clark, H., Clerbaux, C., Coheur, P., Engelen, R. J., Errera, Q., Flemming, J., George, M., Granier, C., Hadji-Lazaro, J., Huijnen, V., Hurtmans, D., Jones, L., Kaiser, J. W., Kapsomenakis, J., Lefever, K., Leitão, J., Razinger, M., Richter, A., Schultz, M. G., Simmons, A. J., Suttie, M., Stein, O., Thépaut, J.-N., Thouret, V., Vrekoussis, M., Zerefos, C., and the MACC team: The MACC reanalysis: an 8 yr data set of atmospheric composition, Atmos. Chem. Phys., 13, 4073-4109, doi:10.5194/acp-13-4073-2013, 2013.

Janhäll, S., Andreae, M. O., and Pöschl, U.: Biomass burning aerosol emissions from vegetation fires: particle number and mass emission factors and size distributions, Atmos. Chem. Phys., 10, 1427-1439, doi:10.5194/acp-10-1427-2010, 2010.

Jimenez, J. L., Canagaratna, M. R., Donahue, N. M., Prevot, A. S. H., Zhang, Q., Kroll, J. H., DeCarlo, P. F., Allan, J. D., Coe, H., Ng, N. L., Aiken, A. C., Docherty, K. S., Ulbrich, I. M., Grieshop, A., P., Robinson, A. L., Duplissy, J., Smith, J. D., Wilson, K., R., Lanz, V. A., Hueglin, C., Sun, Y. L., Tian, J., Laaksonen, A., Raatikainen, T., Rautiainen, J., Vaattovaara, P., Ehn, M., Kulmala, M., Tomlinson, J. M., Collins, D. R., Cubison, M. J., Dunlea, E. J., Huffman, J. A., Onasch, T. B., Alfarra, M. R., Williams, P. I., Bower, K., Kondo, Y., Schneider, J., Drewnick, F., Borrmann, S., Weimer, S., Demerjian, K., Salcedo, D., Cottrell, L., Griffin, R., Takami, A., Miyoshi, T., Hatakeyama, S., Shimono, A., Sun, J. Y., Zhang, Y., M., Dzepina, K., Kimmel, J., R., Sueper, D., Jayne, J. T., Herndon, S. C., Trimborn, A. M., Williams, L. R., Wood, E. C., Middlebrook, A. M., Kolb, C. E., Baltensperger, U., Worsnop, D. R.: Evolution of organic aerosols in the atmosphere, Science, 326, 1525-1529, doi:10.1126/science.1180353, 2009.

Jolleys, M. D., Coe, H., McFiggans, G., Capes, G., Allan, J. D., Crosier, J., Williams, P. I., Allen, G., Bower, K. N., Jimenez, J. L., Russell, L. M., Grutter, M., and Baumgardner, D.: Characterizing the aging of biomass burning organic aerosol by use of mixing ratios: a meta-analysis of four regions, Environ. Sci. Technol., 46, 13093-13102, doi:10.1021/es302386v, 2012.

Kaiser, J. W., Flemming, J., Schultz, M. G., Suttie, M., and Wooster, M. J.: The Global Fire Assimilation System: First Emission Products (GFASv0), Tech. Memo. 596, ECMWF, Reading, UK, 2009.

Kaiser, J. W., Heil, A., Andreae, M. O., Benedetti, A., Chubarova, N., Jones, L., Morcrette, J.-J., Razinger, M., Schultz, M. G., Suttie, M., and van der Werf, G. R.: Biomass burning emissions estimated with a global fire assimilation system based on observed fire radiative power, Biogeosciences, 9 , 527-554, doi:10.5194/bg-9-527-2012, 2012.

Kessler, E.: On the Distribution and Continuity of Water Substance in Atmospheric Circulation Models, Meteorol. Monogr., Vol. 10, Am. Meteorol. Soc., Boston, MA, 1969.

Kotchenruther, R. A. and Hobbs, P. V: Humidification factors of aerosols from biomass burning in Brazil, J. Geophys. Res., 103, 32081, doi:10.1029/98JD00340, 1998.

Lack, D. A., Langridge, J. M., Bahreini, R., Cappa, C. D., Middlebrook, A. M., and Schwarz, J. P.: Brown carbon and internal mixing in biomass burning particles, Proc. Natl. Acad. Sci. USA, 109, 14802-14807, doi:10.1073/pnas.1206575109, 2012.

Lack, D. A., Bahreini, R., Langridge, J. M., Gilman, J. B., and Middlebrook, A. M.: Brown carbon absorption linked to organic mass tracers in biomass burning particles, Atmos. Chem. Phys., 13, 2415-2422, doi:10.5194/acp-13-2415-2013, 2013.

Longo, K. M., Freitas, S. R., Andreae, M. O., Setzer, A., Prins, E., and Artaxo, P.: The Coupled Aerosol and Tracer Transport model to the Brazilian developments on the Regional Atmospheric Modeling System (CATT-BRAMS) - Part 2: Model sensitivity to the biomass burning inventories, Atmos. Chem. Phys., 10, 57855795, doi:10.5194/acp-10-5785-2010, 2010.

Matsui, H., Koike, M., Kondo, Y., Moteki, N., Fast, J. D., and Zaveri, R. A.: Development and validation of a black carbon mixing state resolved three-dimensional model: Aging processes 
and radiative impact, J. Geophys. Res. Atmos., 118, 2304-2326, doi:10.1029/2012JD018446, 2013.

McFiggans, G., Artaxo, P., Baltensperger, U., Coe, H., Facchini, M. C., Feingold, G., Fuzzi, S., Gysel, M., Laaksonen, A., Lohmann, U., Mentel, T. F., Murphy, D. M., O'Dowd, C. D., Snider, J. R., and Weingartner, E.: The effect of physical and chemical aerosol properties on warm cloud droplet activation, Atmos. Chem. Phys., 6, 2593-2649, doi:10.5194/acp-6-25932006, 2006.

McMeeking, G. R., Hamburger, T., Liu, D., Flynn, M., Morgan, W. T., Northway, M., Highwood, E. J., Krejci, R., Allan, J. D., Minikin, A., and Coe, H.: Black carbon measurements in the boundary layer over western and northern Europe, Atmos. Chem. Phys., 10, 9393-9414, doi:10.5194/acp-10-93932010, 2010.

Middlebrook, A. M., Bahreini, R., Jimenez, J. L., and Canagaratna, M. R.: Evaluation of composition-dependent collection efficiencies for the aerodyne aerosol mass spectrometer using field data, Aerosol Sci. Tech., 46, 258-271, doi:10.1080/02786826.2011.620041, 2012.

Mlawer, E. J., Taubman, S. J., Brown, P. D., Iacono, M. J., and Clough, S. A.: Radiative transfer for inhomogeneous atmospheres: RRTM, a validated correlated-k model for the longwave, J. Geophys. Res., 102, 16663-16682, doi:10.1029/97JD00237, 1997.

Morgan, W. T., Allan, J. D., Bower, K. N., Capes, G., Crosier, J., Williams, P. I., and Coe, H.: Vertical distribution of sub-micron aerosol chemical composition from North-Western Europe and the North-East Atlantic, Atmos. Chem. Phys., 9, 5389-5401, doi:10.5194/acp-9-5389-2009, 2009.

Morgan, W. T., Allan, J. D., Flynn, M., Darbyshire, E., Hodgson, A., Johnson, B. T., Haywood, J. M. Freitas, S., Longo, K., Artaxo, P., and Coe, H.: Overview of the South American biomass burning analysis (SAMBBA) field experiment, AIP Conf. Proc., 1527, 587-590, doi:10.1063/1.4803339, 2013.

Morcrette, J.-J., Boucher, O., Jones, L., Salmond, D., Bechtold, P., Beljaars, A., Benedetti, A., Bonet, A., Kaiser, J. W., Razinger, M., Schulz, M., Serrar, S., Simmons, A. J., Sofiev, M., Suttie, M., Tompkins, A. M., and Untch, A.: Aerosol analysis and forecast in the European Centre for Medium-Range Weather Forecasts Integrated Forecast System: forward modeling, J. Geophys. Res., 114, D06206, doi:10.1029/2008JD011235, 2009.

Morrison, H., Curry, J. A., and Khvorostyanov, V. I.: A new doublemoment microphysics parameterization for application in cloud and climate models. Part I: Description, J. Atmos. Sci., 62, 16651677, doi:10.1175/JAS3446.1, 2005.

Müller, T., Laborde, M., Kassell, G., and Wiedensohler, A.: Design and performance of a three-wavelength LED-based total scatter and backscatter integrating nephelometer, Atmos. Meas. Tech., 4, 1291-1303, doi:10.5194/amt-4-1291-2011, 2011.

Ogren, J. A.: Comment on "Calibration and intercomparison of filter-based measurements of visible light absorption by aerosols", Aerosol Sci. Tech., 44, 589-591, doi:10.1080/02786826.2010.482111, 2010.

Ogura, Y. and Takahashi, T.: Numerical simulation of the life cycle of a thunderstorm cell, Mon. Weather Rev., 99, 895-911, 1971.

Olivier, J. G. J., Berdowski, J. J. M., Jeroen, A. H. W., Bakker, J., Visschedijk, A. J. H., and Bloos, J. J.: Applications of EDGAR Including a Description of EDGAR 3.2: Reference Database with Trend Data for 1970-1995, RIVM report no. 773301 001/NOP report no. 410200 051, RIVM, Bilthoven, 2002.

Olson, J. S., Watts, J. A., and Allison, L. J.: Major World Ecosystem Complexes Ranked by Carbon in Live Vegetation: A Database (Revised November 2000), NDP-017, available online at: http: //cdiac.esd.ornl.gov/ndps/ndp017.html (last access: 16 September 2014), Carbon Dioxide Information Analysis Center, Oak Ridge National Laboratory, Oak Ridge, Tennesse, USA, 2000.

Pereira, G., Freitas, S. R., Moraes, E. C., Ferreira, N. J., Shimabukuro, Y. E., Rao, V. B., and Longo, K. M.: Estimating trace gas and aerosol emissions over South America: relationship between fire radiative energy released and aerosol optical depth observations, Atmos. Environ., 43, 6388-6397, doi:10.1016/j.atmosenv.2009.09.013, 2009.

Peterson, D. and Wang, J.: A sub-pixel-based calculation of the fire radiative power from MODIS observations: 2 . Sensitivity analysis and potential fire weather application, Remote Sens. Environ., 129, 231-249, doi:10.1016/j.rse.2012.10.020, 2013.

Peterson, D., Wang, J., Ichoku, C., Hyer, E., and Ambrosia, V.: A sub-pixel-based calculation of the fire radiative power from MODIS observations: 1. Algorithm development and initial assessment, Remote Sens. Environ., 129, 262-279, doi:10.1016/j.rse.2012.10.036, 2013.

Peterson, D., Hyer, E. J. and Wang, J.: Quantifying the potential for high-altitude smoke injection in the North American boreal forest using the standard MODIS fire products and subpixelbased methods, J. Geophys. Res. Atmos., 119, 3401-3419, doi:10.1002/2013JD021067, 2014.

Petrenko, M., Kahn, R., Chin, M., Soja, A., and Kucsera, T.: The use of satellite-measured aerosol optical depth to constrain biomass burning emissions source strength in the global model GOCART, J. Geophys. Res. Atmos., 117, D18212, doi:10.1029/2012JD017870, 2012.

Pincus, R., Barker, H. W., and Morcrette, J.-J.: A fast, flexible, approximate technique for computing radiative transfer in inhomogeneous cloud fields, J. Geophys. Res., 108, 4376, doi:10.1029/2002JD003322, 2003.

Prins, E. M., Feltz, J. M., Menzel, W. P., and Ward, D. E.: An overview of GOES- 8 diurnal fire and smoke results for SCAR-B and 1995 fire season in South America, J. Geophys. Res., 103, 31821-31835, 1998.

Randerson, J. T., Chen, Y., van der Werf, G. R., Rogers, B. M., and Morton, D. C.: Global burned area and biomass burning emissions from small fires, J. Geophys. Res., 117, G04012, doi:10.1029/2012JG002128, 2012.

Reid, J. S., Hobbs, P. V., Ferek, R. J., Blake, D. R., Martins, J. V., Dunlap, M. R. and Liousse, C.: Physical, chemical, and optical properties of regional hazes dominated by smoke in Brazil, J. Geophys. Res., 103, 32059, doi:10.1029/98JD00458, 1998.

Reid, J. S., Koppmann, R., Eck, T. F., and Eleuterio, D. P.: A review of biomass burning emissions part II: intensive physical properties of biomass burning particles, Atmos. Chem. Phys., 5, 799825, doi:10.5194/acp-5-799-2005, 2005.

Reid, S. and Hobbs, P. V.: Physical and optical properties of young smoke from individual biomass fires in Brazil, J. Geophys. Res., 103, 32013-32030, 1998.

Remer, L. A., Kaufman, Y. J., Tanr, D., Mattoo, S., Chu, D. a., Martins, J. V., Li, R.-R., Ichoku, C., Levy, R. C., Kleidman, R. G., Eck, T. F., Vermote, E., and Holben, B. N.: The MODIS aerosol 
algorithm, products, and validation, J. Atmos. Sci., 62, 947-973, doi:10.1175/JAS3385.1, 2005.

Rizzo, L. V., Artaxo, P., Müller, T., Wiedensohler, A., Paixão, M., Cirino, G. G., Arana, A., Swietlicki, E., Roldin, P., Fors, E. O., Wiedemann, K. T., Leal, L. S. M., and Kulmala, M.: Long term measurements of aerosol optical properties at a primary forest site in Amazonia, Atmos. Chem. Phys., 13, 2391-2413, doi:10.5194/acp-13-2391-2013, 2013.

Roberts, G. C. and Nenes, A.: A continuous-flow streamwise thermal-gradient $\mathrm{CCN}$ chamber for atmospheric measurements, Aerosol Sci. Tech., 39, 206-221, doi:10.1080/027868290913988, 2005.

Saleh, R., Robinson, E. S., Tkacik, D. S., Ahern, A. T., Liu, S., Aiken, A. C., Sullivan, R. C., Presto, A. A., Dubey, M. K., Yokelson, R. J., Donahue, N. M., and Robinson, A. L.: Brownness of organics in aerosols from biomass burning linked to their black carbon content, Nat. Geosci., 7, 647-650, doi:10.1038/ngeo2220, 2014.

Samset, B. H. and Myhre, G.: Vertical dependence of black carbon, sulphate and biomass burning aerosol radiative forcing, Geophys. Res. Lett., 38, L24802, doi:10.1029/2011GL049697, 2011.

Samset, B. H., Myhre, G., Schulz, M., Balkanski, Y., Bauer, S., Berntsen, T. K., Bian, H., Bellouin, N., Diehl, T., Easter, R. C., Ghan, S. J., Iversen, T., Kinne, S., Kirkevåg, A., Lamarque, J.-F., Lin, G., Liu, X., Penner, J. E., Seland, Ø., Skeie, R. B., Stier, P., Takemura, T., Tsigaridis, K., and Zhang, K.: Black carbon vertical profiles strongly affect its radiative forcing uncertainty, Atmos. Chem. Phys., 13, 2423-2434, doi:10.5194/acp-13-24232013, 2013.

Schwarz, J. P., Gao, R. S., Spackman, J. R., Watts, L. A., Thomson, D. S., Fahey, D. W., Ryerson, T. B., Peischl, J., Holloway, J. S., Trainer, M., Frost, G. J., Baynard, T., Lack, D. A., de Gouw, J. A., Warneke, C., and Del Negro, L. A.: Measurement of the mixing state, mass, and optical size of individual black carbon particles in urban and biomass burning emissions, Geophys. Res. Lett., 35, L13810, doi:10.1029/2008GL033968, 2008.

Sestini, M., Reimer, E., Valeriano, D., Alvalá, R., Mello, E., Chan, C., and Nobre, C.: Mapa de cobertura da terra da Amazônia legal para uso em modelos meteorológicos, in: Anais XI Simpósio Brasileiro de Sensoriamento Remoto, 2901-2906, 2003.

Setzer, A. and Pereira, M.: Amazonia biomass burnings in 1987 and an estimate of their tropospheric emissions, Ambio, 20, 19-22, 1991.

Shimabukuro, Y. E., Pereira, G., Cardozo, F. S., Stockler, R., Freitas, S. R., and Coura, S. M. C.: Biomass burning emission estimation in Amazon tropical forest, in: Earth Observation of Ecosystem Services, 1st Edn., edited by: Segura, D. A., Di Bella, C. M., Straschnoy, J. V., Taylor \& Francis, Oxford, UK, 112-130, 2013.

Shiraiwa, M., Kondo, Y., Moteki, N., Takegawa, N., Sahu, L. K., Takami, A., Hatakeyama, S., Yonemura, S., and Blake, D. R.: Radiative impact of mixing state of black carbon aerosol in Asian outflow, J. Geophys. Res., 113, D24210, doi:10.1029/2008JD010546, 2008.

Shrivastava, M., Fast, J., Easter, R., Gustafson Jr., W. I., Zaveri, R. A., Jimenez, J. L., Saide, P., and Hodzic, A.: Modeling organic aerosols in a megacity: comparison of simple and complex representations of the volatility basis set approach, At- mos. Chem. Phys., 11, 6639-6662, doi:10.5194/acp-11-66392011, 2011.

Shrivastava, M., Berg, L. K., Fast, J. D., Easter, R. C., Laskin, A., Chapman Jr., E. G., Gustafson, W. I., Ying, L., Berkowitz, C. M.: Modeling aerosols and their interactions with shallow cumuli during the 2007 CHAPS field study, J. Geophys. Res.-Atmos., 118, 1343-1360, 2013.

Sofiev, M., Vankevich, R., Ermakova, T., and Hakkarainen, J.: Global mapping of maximum emission heights and resulting vertical profiles of wildfire emissions, Atmos. Chem. Phys., 13, 7039-7052, doi:10.5194/acp-13-7039-2013, 2013.

Stein, O., Flemming, J., Inness, A., and Kaiser, J. W.: Global reactive gases forecasts and reanalysis in the MACC project, J. Integr. Environ. Sci., 9, 1-14, doi:10.1080/1943815X.2012.696545, 2012.

Stephens, M., Turner, N., and Sandberg, J.: Particle identification by laser-induced incandescence in a solid-state laser cavity, Appl. Optics, 42, 3726-3736, 2003.

Stockwell, W. R., Middleton, P., Chang, J. S., and Tang, X.: The second-generation regional acid deposition model chemical mechanism for regional air quality modeling, J. Geophys. Res., 95, 16343-16367, 1990.

Stockwell, W. R., Kirchner, F., Kuhn, M., and Seefeld, S.: A new mechanism for regional atmospheric chemistry modeling, J. Geophys. Res., 102, 25847-25979, 1997.

Streets, D. G., Bond, T. C., Lee, T., and Jang, C.: On the future of carbonaceous aerosol emissions, J. Geophys. Res., 109, D24212, doi:10.1029/2004JD004902, 2004.

Taylor, J. W., Allan, J. D., Allen, G., Coe, H., Williams, P. I., Flynn, M. J., Le Breton, M., Muller, J. B. A., Percival, C. J., Oram, D., Forster, G., Lee, J. D., Rickard, A. R., Parrington, M., and Palmer, P. I.: Size-dependent wet removal of black carbon in Canadian biomass burning plumes, Atmos. Chem. Phys., 14, 13755-13771, doi:10.5194/acp-14-13755-2014, 2014

Toon, O. B. and Ackerman, T. P.: Algorithms for the calculation of scattering by stratified spheres, Appl. Optics, 20, 3657-3660, 1981.

Tosca, M. G., Randerson, J. T., and Zender, C. S.: Global impact of smoke aerosols from landscape fires on climate and the Hadley circulation, Atmos. Chem. Phys., 13, 5227-5241, doi:10.5194/acp-13-5227-2013, 2013.

Trembath, J. A.: Airborne CCN Measurements, Ph.D. thesis, School of Earth, Atmospheric and Environmental Sciences, University of Manchester, UK, 268 pp., available at: https://www.escholar. manchester.ac.uk/item/?pid=uk-ac-man-scw:212956 (last access: 2 March 2015), 2013.

Turnbull, K.: PSAP Corrections: Amendment to MRF Technical Note No. 31, OBR Technical Note, No. 80, Met Office, August 2010.

Turpin, B. J. and Lim, H.-J.: Species contributions to $\mathrm{PM}_{2.5}$ mass concentrations: revisiting common assumptions for estimating organic mass, Aerosol Sci. Tech., 35, 602-610, 2001.

Vakkari, V., Kerminen, V.-M., Beukes, J. P., Tiitta, P., van Zyl, P. G., Josipovic, M., Venter, A. D., Jaars, K., Worsnop, D. R., Kulmala, M., and Laksso, L.: Rapid changes in biomass burning aerosols by atmospheric oxidation, Geophys. Res. Lett., 41, 2644-2651, doi:10.1002/2014GL059396, 2014.

Val Martin, M., Logan, J. A., Kahn, R. A., Leung, F.-Y., Nelson, D. L., and Diner, D. J.: Smoke injection heights from fires 
in North America: analysis of 5 years of satellite observations, Atmos. Chem. Phys., 10, 1491-1510, doi:10.5194/acp-10-14912010, 2010.

van der Werf, G. R., Randerson, J. T., Giglio, L., Collatz, G. J., Kasibhatla, P. S., and Arellano Jr., A. F.: Interannual variability in global biomass burning emissions from 1997 to 2004, Atmos. Chem. Phys., 6, 3423-3441, doi:10.5194/acp-6-3423-2006, 2006.

van der Werf, G. R., Randerson, J. T., Giglio, L., Collatz, G. J., Mu, M., Kasibhatla, P. S., Morton, D. C., DeFries, R. S., Jin, Y., and van Leeuwen, T. T.: Global fire emissions and the contribution of deforestation, savanna, forest, agricultural, and peat fires (1997-2009), Atmos. Chem. Phys., 10, 11707-11735, doi:10.5194/acp-10-11707-2010, 2010.

Viegas, D. X.: Forest fire propagation, Philos. T. Roy. Soc. A, 356, 2907-2928, doi:10.1098/rsta.1998.0303, 1998.

Wang, J. and Christopher, S. A.: Mesoscale modeling of Central American smoke transport to the United States: 2. Smoke radiative impact on regional surface energy budget and boundary layer evolution, J. Geophys. Res., 111, D14S92, doi:10.1029/2005JD006720, 2006.

Wang, J., Christopher, S. A., Nair, U. S., Reid, J. S., Prins, E. M., Szykman, J., and Hand, J. L.: Mesoscale modeling of Central American smoke transport to the United States: 1. "Top-down" assessment of emission strength and diurnal variation impacts, J. Geophys. Res., 111, D05S17, doi:10.1029/2005JD006416, 2006.

Wang, J., Ge, C., Yang, Z., Hyer, E. J., Reid, J. S., Chew, B.-N., Mahmud, M., Zhang, Y., and Zhang, M.: Mesoscale modeling of smoke transport over the Southeast Asian Maritime Continent: Interplay of sea breeze, trade wind, typhoon, and topography, Atmos. Res., 122, 486-503, doi:10.1016/j.atmosres.2012.05.009, 2013.

Wang, S. C. and Flagan, R. C.: Scanning electrical mobility spectrometer, Aerosol Sci. Technol., 13, 230-240, doi:10.1080/02786829008959441, 1990.
Wu, L., Su, H., and Jiang, J. H.: Regional simulations of deep convection and biomass burning over South America: 1. Model evaluations using multiple satellite data sets, J. Geophys. Res., 116, D17208, doi:10.1029/2011JD016106, 2011a.

Wu, L., Su, H., and Jiang, J. H.: Regional simulations of deep convection and biomass burning over South America: 2. Biomass burning aerosol effects on clouds and precipitation, J. Geophys. Res., 116, D17209, doi:10.1029/2011JD016106, 2011b.

Yang, Z., Wang, J., Ichoku, C., Hyer, E., and Zeng, J.: Mesoscale modeling and satellite observation of transport and mixing of smoke and dust particles over northern sub-Saharan African region, J. Geophys. Res. Atmos., 118, 12139-12157, doi:10.1002/2013JD020644, 2013.

Yevich, R. and Logan, J. A.: An assessment of biofuel use and burning of agricultural waste in the developing world, Global Biogeochem. Cy., 17, 1095, doi:10.1029/2002GB001952, 2003.

Zaveri, R. A. and Peters, L. K.: A new lumped structure photochemical mechanism for large-scale applications, J. Geophys. Res., 104, 30387-30415, 1999.

Zaveri, R. A., Easter, R. C., Fast, J. D., and Peters, L. K.: Model for Simulating Aerosol Interactions and Chemistry (MOSAIC), J. Geophys. Res., 113, D132024, doi:10.1029/2007JD008782, 2008.

Zhang, D. and Anthes, R. A.: High-resolution model of the planetary boundary layer - sensitivity tests and comparisons with SESAME-79 data, J. Appl. Meteorol., 21, 1594-1609, 1982.

Zhang, F., Wang, J., Ichoku, C., Hyer, E. J., Yang, Z., Ge, C., Su, S., Zhang, X., Kondragunta, S., Kaiser, J. W., Wiedinmyer, C., and da Silva, A.: Sensitivity of mesoscale modeling of smoke direct radiative effect to the emission inventory: a case study in northern sub-Saharan African region, Environ. Res. Lett., 9, 075002, doi:10.1088/1748-9326/9/7/075002, 2014.

Zhang, Y., Fu, R., Yu, H., Qian, Y., Dickinson, R., Silva Dias, M. A. F., da Silva Dias, P. L., and Fernandes, K.: Impact of biomass burning aerosol on the monsoon circulation transition over Amazonia, Geophys. Res. Lett., 36, L10814, doi:10.1029/2009GL037180, 2009. 